\title{
A Critical Review of the Precursors of the Knowledge Economy and Their Contemporary Research: Implications for the Computerized New Economy
}

\author{
Kwee Keong Choong ${ }^{1}$ Patrick W. Leung ${ }^{2}$
}

Received: 19 July 2020 / Accepted: 19 January 2021 / Published online: 26 March 2021

(c) The Author(s), under exclusive licence to Springer Science+Business Media, LLC part of Springer Nature 2021

\begin{abstract}
Despite nearly fifty-eight years since the term knowledge economy first appears, we are getting nearer in understanding this new kind of economy. The purpose of this paper is to clarify the meaning of the knowledge economy by conducting a critical review of the precursors of the knowledge economy and their major critiques so as to identify the current research implications. We aim to identify common ground in advancing the research of the knowledge economy. In essence, our understanding of the knowledge economy is viewed from a 'new' social-economictheoretical perspective in which the theoretical foundation focuses on the explosion of technology that motivates people to be innovative and possess knowledge in producing knowledge products or be so engrossed with sociability using technology at home. Our finding is that the notion of the knowledge economy must be viewed from some phenomena that have transformed the contemporary economy. Other major findings include the following: (1) we use the term knowledge economy instead of the multiplicity of terms to describe this new form of economy; (2) we articulate that the theoretical foundation of the knowledge economy is a branch of social economy where the economy is not based solely on production and consumption but is based more on social values, technology, knowledge and innovation to commercialize knowledge products; and (3) the statistical assessment methodology is delivered through the use of indicators to proxy for the four knowledge economy criteria that makes up the knowledge economy. This has the following implications for economic management, knowledge-induced innovation, computerization of the economy, and knowledge management in the new economy.
\end{abstract}

Keywords Knowledge economy $\cdot$ Knowledge society $\cdot$ Knowledge age $\cdot$ Information economy $\cdot$ Information age $\cdot$ Social economy

Kwee Keong Choong

kchmoon88@gmail.com

Extended author information available on the last page of the article 


\section{Introduction}

The field of the knowledge economy is receiving tremendous interest. Isenberg (2010) reported that there were 40,000 articles on the knowledge and knowledgebased economies as at 2010 and there is a multiplicity of terms being used to describe similar concepts related to knowledge management (Davenport, 2005; Nonaka \& Takeuchi, 1995), knowledge economy (Drucker, 1969; 1973, 1999), knowledge industry (Machlup, 1962; Machlup \& Mansfield, 1970), information economy (Porat, 1977; Porat \& Rubin, 1977) and network society (Castells, 1997; Van Dijk, 1999, 2006). In view of the hefty of terms used, they can collectively be labelled as the knowledge economy (KE), and their authors are avowed as the precursors of the KE. However, nearly 58 years since Machlup's seminal work on the KE, we are now getting nearer in understanding this new kind of economy. Initially, significant doubts arise as to whether the 'modern economies' are, indeed, 'knowledge economies'. More critically, the current economic meltdown and the Covid-19 pandemic of these so-called knowledge economies are testimonies of false assertion by the precursors of the field, and most recently, the current medical pandemic has cast further doubt on the sustainability that the developed economies are knowledge economy. Such inadequacy occurs in view of the fact that the field has no shortage of writers and critics that advance or reject various avenues of the knowledge economy. So, what actually is 'knowledge economy'?

The objective of this paper is to understand by questioning and reasoning by what the precursors meant by 'knowledge economy' and not on what they have explained in a casual manner. We also want to know whether similar terms like 'knowledge-based economy', 'information economy' or 'knowledge society' meant the same or different things, and even if they were used merely for semantic reasons, is there a common ground for us to specify a research agenda that enables us in the furtherance of the study of the field in a systematic manner? The objective is also to find the implications for economic management, computerization of the economy and knowledge management in the new economy. Therefore, this paper will make a contribution to the literature in the areas of the theory and management of the knowledge economy as it provides a new perspective of the issues in the emergence and operation of the knowledge economy, providing a better understanding of the computerized new economy.

In doing the above, we use a methodology comprising a systematic review, content analysis and critical theory (analysis) in helping us to examine the terms and contents used to describe a knowledge economy. The next section examines what the precursors of the knowledge economy have told us. In 'Commentary of the Precursors of the Knowledge Economy', we critically review what the critics of the precursors have told us, and explain what is wrong with the current reality of the knowledge economy. 'Theoretical consideration in advancing the research on the knowledge economy' is concerned with avenues in advancing the research of the knowledge economy. 'Conclusions and Discussion' reports the findings of the paper and their implications and concludes our discussion of this research. 


\section{Methodology}

\section{A Systematic Review of the Literature}

According to Godin (2010), the works of the precursors of the knowledge economy can be divided into two waves of studies pertaining to the field. The works of Machlup, Mansfield, Drucker, Bell, Porat and Rubin are considered the first wave of studies on the knowledge economy, and the second wave started in the mid-1990s that revitalizes the studies in the first wave with a change in emphasis and continues today. The notable works of this second wave are Nonaka, Takeuchi, von Krogh, Davenport, Prusak and Volpel, Van Dijk, Castells, United Nations (UN), United Nations Educational, Scientific and Cultural Organizations (UNESCO) and the Organization for Economic Cooperation Development (OECD). Although the works of the UN, UNESCO and the OECD are not really seminal, aspects of their works have merits and, hence, can be considered as precursors of the second wave. This assertion by Godin (2010) is consistent to the Handbook on the Knowledge Economy by Rooney et al. (2005).

Since we already know who the precursors are, the next step is to use the surnames of the precursors comprising 'machlup', 'drucker', 'bell', 'rubin', 'nonaka', 'takeuchi', 'von krogh', 'davenport', 'prusak', 'volpel', 'van dijk', 'castell', 'UN', 'UNESCO' and 'OECD' (altogether, fifteen names) to conduct a literature search to find who are the followers and critiques of these precursors. The search criterion for the publication period is from 1980 and 2020 (41 years), but the disciplines of the journals (e.g. management or production) are not set as a criterion for the literature search so as to obtain as many articles as possible. The starting year chosen is due to data availability as most search engines are not able to locate articles prior to 1980 (Choong, 2014). The literature search is based on a systematic review methodology as it is preferred to the traditional literature review because the former is particularly suited in a large literature survey for the gathering, evaluating and analysing of all the available articles relevant to a set of research questions (RQ) (Leseure et al., 2004; Kitchenham \& Charters, 2007; Choong, 2014).

All literature searches were conducted using major journal databases such as ABI/Inform ProQuest, Emerald Full Text, Scopus and EBSCO. To be very certain that no relevant articles were left out from the literature search, a search was conducted on the Internet using Google Scholar for any publications pertaining to this research from 1980 onwards. While this procedure did not guarantee an exhaustive collection of all relevant knowledge economy articles, we believe that a large majority of relevant papers were found, and the resulting findings from this research suffice to provide a strong conclusion concerning the topic of the knowledge economy. 


\section{Content Analysis}

Content analysis needs no introduction as it is a widely used method in social sciences and humanities to identify commonalities (common grounds) for studying and/or retrieving meaningful information from documents (Krippendorff, 2004; Jones, 2019) oriented to the study of 'mute evidence' of texts and artefacts (Hodder, 1994, p. 155). Content analysis involves the selection of articles that have a high content of a research question, not people. But no matter how hard one tries, one just cannot analyse content in all possible ways, and this means it is impossible to be comprehensive. Hence, after the analysis, you will usually want to generalize those findings to a broader context-in other words, you are hoping that the issue you selected is a representative sample. Although content analysis is usually used to analyse written words, it is a quantitative method. The results of content analysis are numbers or counts, for example, how many authors use the term 'knowledge economy' as compared with those using 'information economy'. The numbers and counting serve two purposes: to (1) remove much of the subjectivity from summaries and (2) to simplify the detection of trends. These help to aid human judgement in assigning relevance to the content.

\section{Critical Analysis}

Critical theory is well suited for this research as writing about the knowledge economy (which is considered a social science) is in many ways subjective where terms are used discriminately, and there is no cohesive body of thoughts (theory) in explaining what this form of economy is about. Critical theory is all about challenging what we have been told; it does enable us in developing a universally coherent study of the field through critical analysis and objective assessment of the content of articles.

In particular, we follow the Horkheimer's (1982) approach in applying critical theory in structuring our paper. This is because Horkheimer wanted to distinguish critical theory as a radical, emancipatory form of social theory oriented toward critiquing and changing society as a whole in its historical specificity - it provides the descriptive and normative bases for social inquiry aimed at meeting three criteria: it must be explanatory, practical, and normative, all at the same time. Thus, Horkheimer's approach is most consistent to the knowledge economy/society because it must explain why the knowledge economy cannot fit with current economic and social reality, identify the actors/phenomenon that bring about the change and provide both clear norms for criticism and achievable, practical goals for economic and social transformation.

\section{The Precursors of the Knowledge Economy}

Here, based on Rooney et al. (2005), and Godin (2010), we review and summarize the fundamentals of the KE divided into two subsections: (1) the first wave of studies on the knowledge economy and (2) the second wave of studies on the knowledge economy. 


\section{The First Wave of Studies on the Knowledge Economy}

The first economist to write about the new economic direction of policymakers was the notable Austrian economist, Fritz Machlup (1902-1983). In The Production and Distribution of Knowledge in the United States, Machlup (1962) defined knowledge and prescribed the usefulness of knowledge in multi-facet perspective, especially on how it is used in production in creating the knowledge industry. In 1970, with Una Mansfield, they emphasized that education provides important impetus in creating a society that relies on information and knowledge in creating jobs and foster growth and the knowledge sector is increasingly growing in importance. In particular, Machlup's books give rise to a new idea of learning and discourse that could impact an economy, now termed as the knowledge economy.

Peter Drucker (1909-2005), another Austrian economist, was quick to capitalize on Machlup's idea when he wrote The Age of Discontinuity (Drucker, 1992a) where the term knowledge workers was used for the first time. To Drucker, knowledge workers differ from manual workers as the former, mainly work with their heads, not hands, and produce ideas, knowledge and information. Drucker was describing these changes in the US economy during the 1930 s when $R \& D$ departments were just blossoming in organizations. The emergence of knowledge workers causes changes in social, political and economic factors in the USA, resulted in the emergence of the KE.

The pace of the change in the US economy quickened in the late 1960s and early 1970s where there was a sudden influx of service workers in big towns and cities from rural farms - the most obvious measure of the transition from manufacturing to a service-based economy. To capture this change, Daniel Bell (1919-2011), a US sociologist and a neo-conservative, in The Coming of PostIndustrial Society (Bell, 1973), hypothesized that a new form of society, coined as the post-industrial society, will emerge in the USA and in other developed countries. This idea is 'primarily' about the change in US society brought about by changes in the economy, nature of work and politics from a nation producing goods to one based on a service economy. He asserted that the postindustrialized economy is not universal as it relates only to those countries that have successfully transformed from an agricultural economy to manufacturing economy. Later, Bell (1979) renamed this concept the Information Society (IS), for which he continued to discuss the significance of information and education in the creation of knowledge.

In 1977, Marc Uri Porat and Michael Rubin, both employees at the US Department of Commerce, wrote a Federal policy handbook that measured and estimated the size of the 'information activity' of the US economy, which is called the Information Economy (IE). They found that the creation, handling and distribution of information were fast becoming a major economic activity for all nations of the world, be they rich or poor, developed or less developed. Porat and Rubin's works have since been used in the USA, several countries and the OECD in describing the information economy. 


\section{The Second Wave of Studies on the Knowledge Economy}

Nonaka and associates provided a new framework in the study of knowledge as (i) knowing and (ii) valued products produced by knowledge workers (Nonaka, 1991, 1994; Nonaka \& Takeuchi, 1995). Nonaka and Takeuchi (1995) conceive that human knowledge can be differentiated between explicit and tacit knowledge- the hallmark of their thesis. Explicit knowledge is 'knowing that' knowledge we can express and is contained in manuals and procedures; hence, it is coded and transferable, and tacit knowledge is scientifically articulated as ineffable or 'knowing how' (knowledge we cannot express) (Polanyi, 1966). Tacit knowledge is learned only by experience, and communicated only indirectly, through metaphor and analogy (Nonaka \& Takeuchi, 1995, p. 58-63). Later with von Krogh (von Krogh et al., 2000a; Nonaka \& von Krogh, 2009), they hypothesized that successful knowledge creation activities are supported by a SECI model, the acronym for Socialization, Externalization, Combination and Internalization. The works of Nonaka (1991, 1994), Nonaka \& Takeuchi (1995) and Von Krogh et al. (2000a, b) are regarded as the precursors of Knowledge Management (KM).

Davenport and colleagues adopted part of Nonaka and Takeuchi's conceptualization of human knowledge and indicated that by transferring their tacit knowledge to fellow workers, knowledge workers have a more vital role to play in the contribution of business strategy (Davenport \& Prusak, 1998; Davenport \& Völpel, 2001; Davenport, 2005). They argued that it is the tacit knowledge that is crucial to management as it is embedded in organizational routines, processes, practices, norms and innovations. As yet, a theory of knowledge management has not been reached (Pawlowski \& Bick, 2012, p. 96).

At about the same time, the Dutch information sociologist, Jan van Dijk, defined the Network Society (NS) as a 'social formation with an infrastructure of social and media networks enabling its prime mode of organization at all levels (individual, group, organizational \& societal)' (2006, p. 20). He observed that in the era of widespread use of microcomputers, the Internet and various IT devices link people and organizations together, and that when a society has attained these forms of informational and network structures, society is in a process of becoming a network society. Under a similar vein, Manuel Castells, the Spanish information sociologist, extends the information age trilogy to the NS and emphasizes the importance of networking (Castells, 1997, 2010). He argued that in the information age, the increasing use of networks '.. . constitute the new social morphology of our societies, and the diffusion of networking logic substantially modifies the operation and outcomes in processes of production, experience, power, and culture' (Castells, 2010, p. 500).

To UNESCO, according to its General Sub-Director for Communication and Information, Abdul Waheed Khan, the concept of knowledge societies $(K S)$ is preferable to that of the 'information society' because the former includes a dimension of social, cultural, economic, political and institutional transformation: collectively, a more pluralistic and developmental perspective that better captures the complexity and dynamism of the changes taking place (UNESCO, 2003, p. 
7-8). Thinking that the term and its expression are perfunctory and have not gone far enough, the OECD changed its inculcation theme by defining it as the knowledgebased economies (KBE). The OECD (1996a, p. 3) defined the KBE as "economies which are directly based on the production, distribution and use of knowledge and information' that represents the emergence of a 'super' economy that is knowledgebased which brings in many benefits, and thus, developing countries should utilize knowledge and the creation and sharing of knowledge across countries in order to reap these benefits.

In more recent development, the European Bank for Reconstruction and Development (EBRD) advances the concept of the knowledge economy as a part of economic development, in which innovation and access to information drive productivity growth (EBRD, 2019). New trends, such as the Internet of Things (IoT) or digitalization, are examples of key elements of the transition towards the knowledge economy. To measure the discerned knowledge economy, the Bank has constructed the EBRD Knowledge Economy Index, spanning 46 economies (38 where the EBRD invests and eight comparators (members of the Organisation for Economic Co-operation and Development, OECD)) divided into four pillars of long-term knowledge-enhancing activities: (1) institutions for innovation, (2) skills for innovation, (3) innovation system and (4) ICT infrastructure. Among the EBRD regions, Estonia scores highest and Turkmenistan lowest.

In sum, the various terms used and the gist of the writings by the precursors of the knowledge economy/society are depicted in Table 1.

There are eight terms prescribing the knowledge economy/society or variation of such economy/society. For instance, Machlup was discussing about the knowledge industry while Drucker talked about the knowledge economy. Nonaka and Takeuchi and associates centre on knowledge, and knowledge creation within an organization, and when these activities are aggregated on a macro level, a kind of KE emerges. Van Dijk and Castells discussed about the network society. This multiplicity of terms is confusing as they can describe either the same or different things, and this inevitably spur scholars and critics (including us) to question the assumptions and rationale behind the work of the precursors. To us, we want to know whether the various terms are used in a casual manner or there is a serious discourse to refer to the knowledge economy. In our content analysis, we found that 91 out of the 121 articles (76\%) in our References use the term 'knowledge economy' which confirms our earlier assertion that this term is most commonly used to describe this kind of the new economy.

\section{Commentary of the Precursors of the Knowledge Economy}

\section{The First Wave of Studies on the Knowledge Economy}

The commentators of Machlup's thesis of an information and knowledge industry indicated that it lacks traditional economic theoretical foundation (Godin, 2006, 2010) and subjective methodology in formulating models (Apte \& Nath, 2004; Connell, 2007). At best, it only provides a crude retrospective approximation of 


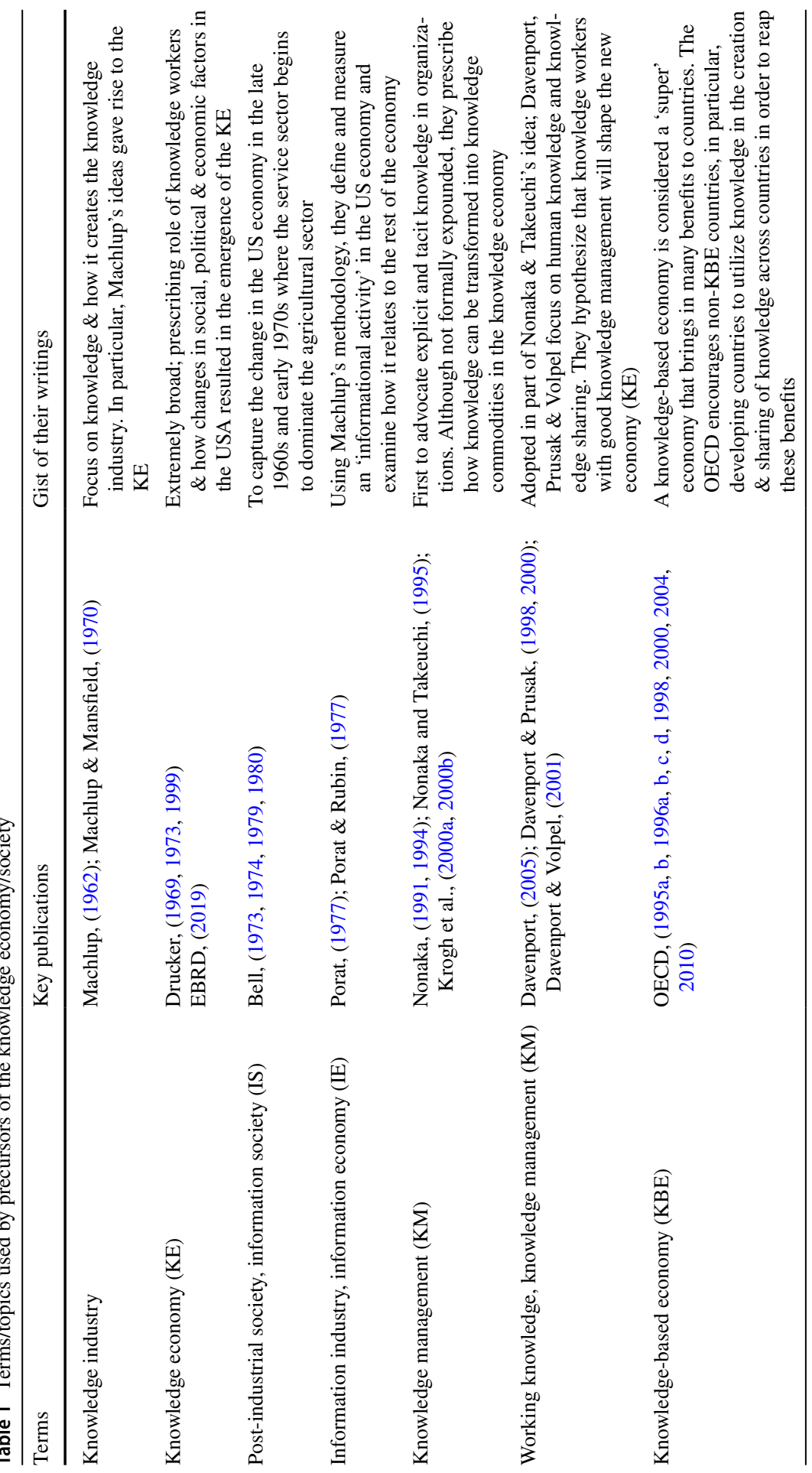




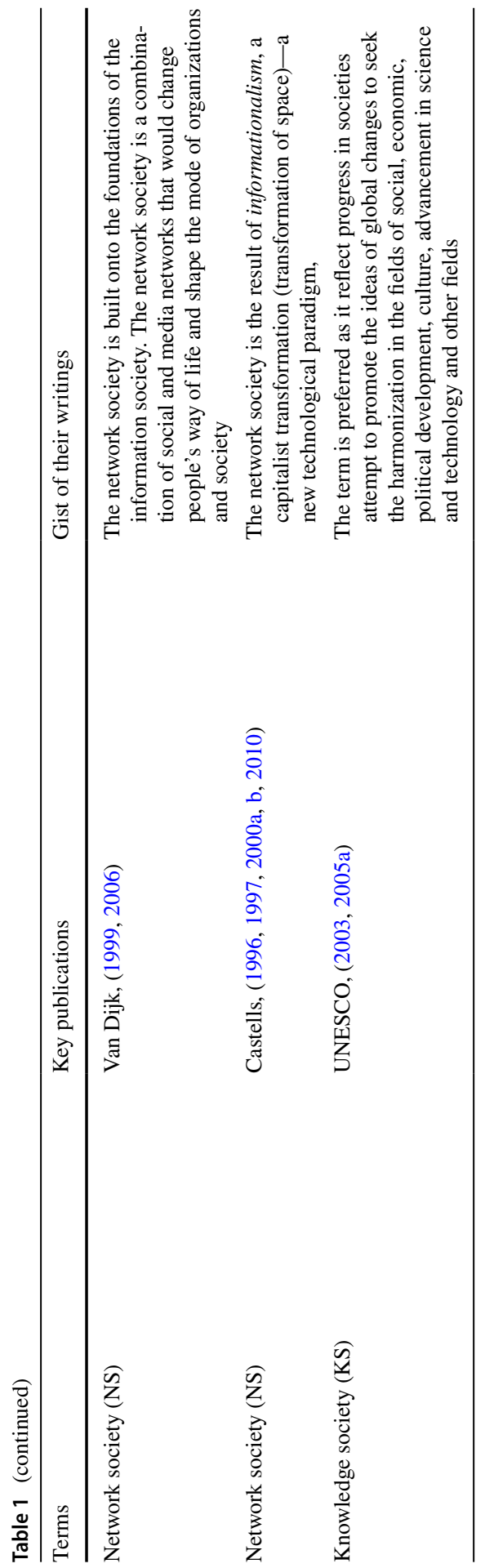


modern economies (Ormerod, 1997), and there are scepticisms about data and his analysis (Godin, 2010). More specifically, Machlup's definition of knowledge is ambiguous and his definition of the 'knowledge industry' was extremely wide, encompassing everything from the production of typewriters and filing cabinets to electronic, print advertising and mass media (Godin, 2008, 2010). Arrow (1984, p. 142-3) stated that Machlup's definition of the knowledge/information economy runs contrary (flaw) to the economic 'meaning of information is precisely a reduction in uncertainty', which would exclude 'information producing' activity such as advertising, market research and most reports about the new economy. In our content and critical analyses, while we concur with the commentators that Machlup's works lack theory (including poor definition of the knowledge and its industry), we acknowledge his meritorious work in the advancement of knowledge and its usefulness in production, and this sector is increasingly growing in importance. And this has proven right.

Drucker's writings have been criticized for lacking academic and scholarly content where principles were far from obvious or still not defined (Parkinson et al., 1987; Edersheim, 2007), for being contradicting (Parkinson et al., 1987) and for being cryptic in his pronouncements as his works lack empirically testable propositions (Edersheim, 2007; Sapru, 2008). Drucker portrays knowledge workers as the preferred workers in a society which is akin to 'brains over brawns' in an economy where knowledge, knowledge management and skills dominate (Hadad, 2017). To Drucker, knowledge workers are the key to innovation and knowledge to an organization, and having them would enable organization to generate new products and inventions. In our analysis, although we do find Drucker's writings to lack academic fervour, to be sometimes contradicting and to be apt in making arresting generalizations rather than to offering rigorous arguments in advancing a rationale of what actually is the $\mathrm{KE}$, we do find meritorious aspects of his work, especially with respect to the notion that knowledge workers are the ones that give ideas and knowledge that initiate $R \& D$ activities in firms in boosting capability and the advancement of an economy.

Bell's writings have been described as wide and to use imprecise terms (Waters, 1996). Gorz (1982, p. 84) argued that the economic activities during the industrial era and Bell's post-industrial economy era are basically the same. Robins and Webster (1999, p. 80) stated that the information society, in fact, 'can be, and has been-achieved on the basis of minimal technological support.' Such assumptions are ideological in nature because they would fit with the view that we can do nothing about change and have to adapt to existing political realities (Webster, 2004a p. 267). Critiques (Gorz, 1982; Giddens, 1990; Waters, 1996; Robins \& Webster, 1999; Mackay, 2001; Webster, 2002a, b; Cornish, 2011) argue that the growth of information does not alter the attributes of the overall capitalist structure. Our content analysis indicates that the term post-industrial society originated from Alain Touraine (1925-) where many facets of his ideas such as the shaping of a 'newer' form of society through structural mechanisms (management, production, organization, distribution) are not much different from Bell's indication that as wealth increases through incomes generated by workers, new demands arise for 'luxury'; personal services such as hotels, restaurants and entertainment; and the demands for the government to provide for better health and education services. 
This, in our view, is a logical extension of economic activities from an industrial society to a post-industrial society, and thus, the terms post-industrial economy and post-industrial society are synonymous.

The studies of Porat and Rubin have been criticized for the lack theoretical building blocks (Miles, 1990; Engelbrecht, 1997; Wellenius, 1988; Apte \& Nath, 2004), use of inappropriate measurement systems (Engelbrecht, 1997; Wellenius, 1988; Apte \& Nath, 2004), lackluster categorization methodology (Apte \& Nath, 2004), use of unadjusted statistics which may inflate the size of the information economy (Apte \& Nath, 2004) and the reflecting of a mixture of information and service-business activities rather than knowledge (Arrow, 1984). Our content analysis confirms these critiques' assertions that the assertion and reported numbers of Porat and Rubin lack measurement theory, and there was inadequate classification between information and non-information activities. Let us elaborate. First, the data reported by Porat and Rubin was obtained from government statistics where the various production and service activities are measured on the traditional value-added basis rather than on innovative or information-based basis. Due to this, actual information activities are not differentiated from economic activities. Second, due to inadequate classification between information and non-information activities, goods and jobs, we consider the actual size of the information economy as advocated by Porat and Rubin to be overstated. Third, we argue that even if we accept Porat and Rubin's classification and measurement methodology, new information activities continually emerge with the advent of new technology, the application varies and the nature and scope of occupations have been continually changing making it imperative that the list of information activities, application and occupations be evaluated and updated regularly. Fourth, we notice that much of Porat and Rubin's ideas are derived from earlier precursors (i.e. Machlup and Drucker) with little innovation of their own, and thus their works do not sit well in rigorous academic research.

\section{The Second Wave of Studies on the Knowledge Economy}

The works of Nonaka (1991, 1994) and Nonaka and Takeuchi (1995) have attracted numerous commentaries and relentless attacks for their (1) conception of knowledge and (2) knowledge creation (innovation) and knowledge management. First, critiques such as Jorna (1998), Wilson (2002), Hildreth and Kimble (2002) and Gourlay (2006) have criticized that Nonaka and his co-authors link tacit knowledge to an EastAsian phenomenological epistemology that is heavily influenced by Confucianism, Zen Buddhism and the collectivism culture of East Asia when putting forward their tacit and explicit knowledge arguments in advancing the concept of knowledge for commercialization. Second, Nonaka and Takeuchi's SECI framework is subjected to the critiques that it is oversimplified in catering for knowledge management as the articulation of knowledge appeared to be possible even for tacit knowledge, and their statement that the sharing of knowledge can be achieved through a socialization process seems obnoxious (Jorna, 1998; Choo, 1998; Wilson, 2002; Hildreth \& Kimble, 2002; Swan \& Scarborough, 2002; Styhre, 2003; Kupers, 2005; Gourlay, 2006). 
We consider the criticisms of Nonaka and Takeuchi on both counts to be misguided, myopic and unwarranted in many respects. First, basing on content and critical analysis, the critiques against Nonaka and Takeuchi of using non-Western epistemology in advancing an interesting new phenomenon of firms using knowledge in managing activities that can improve a country's competitiveness are not based on constructive substantiation or hard evidence that there is any fallacy of East Asian philosophy as used in knowledge application. We also argue that the study of knowledge has been heavily undertaken in East Asia for thousands of years where Confucianism, Shintoism, Taoism and Buddhism play a great part in instilling what knowledge is about. We however, recognize that there are differences in the approach between East Asian and Western epistemology, but the outcome is likely to be the same. Based on the prevailing traditional Western epistemologies, knowledge has mainly been gained through observation and reasoning; however, in traditional Chinese thought, knowledge has been understood in a much broader sense (Rosker, 2014). More specifically, Western philosophy is about dialectics which contains thesis and antithesis and how they are resolved through synthesis, whereas in Eastern philosophy, a phenomenon such as KM is viewed as inherently paradoxical where the interrelatedness of the phenomenon in question is in terms of opposites that neither compromise nor repel each other but rather work in the dynamic combination of those dual entities and thereby build a composite whole (Chae \& Bloodgood, 2006). They state that knowledge exists in the form of both tacit and explicit and, as such, social and technical, together building one composite whole - the Tao or the 'ideal' approach to $\mathrm{KM}$-implying that in duality, unity is found (Chae \& Bloodgood, 2006, p. 7). As a consequent, these critiques fail to see and understand how Eastern countries such as China, Japan, South Korea and Taiwan (China) have successfully managed knowledge in pursuing innovations and inventions.

Second, in retrospect, Nonaka and Takeuchi had indicated that their approach in establishing a workable knowledge-based model is still ongoing and various aspects of work still remain to be done and called for more research to validate his model. Instead, these critiques merely argued that tacit knowledge is difficult to articulate, and hence it is quite impossible to transfer since 'tacit' means 'hidden', and that tacit knowledge is hidden knowledge. This testimony is nothing new as it was posited by Polanyi (1958), but these critiques failed to understand that in Nonaka \& Takeuchi's thesis, tacit knowledge alone does not suffice, that a socialization process is needed to transfer tacit to explicit knowledge in creating knowledge outcome. Notwithstanding these criticisms, the SECI framework has now attracted many prominent researchers such as von Krough, Davenport, Prusak and Volpel and they have contributed to the refinement of the framework.

Opponents of van Dijk's network society consider that his form of society organized around global networks of capital, social, management and information through the multiplicity of interconnected tasks to be nothing more than a contemporary society (Fuchs, 2009). There is nothing theoretical about how a society can become a network society besides by stating propositions and facts that are currently in existence (Webster, 2002a, b, 2004). From the writings of critiques, we detected that there are two key issues of the network society as advocated by van Dijk. First, this kind of network society may only be achieved partially as it depends 
on high educational attainment and high educational use (see Di Maggio \& Celeste, 2004) and is perceived in creating a digital divide (see Norris, 2001; Nakata, 2002; Rice \& Haythornthwaite, 2006; Abdulla, 2007; Sharma et al., 2008; Allagui, 2009). To us, the reported increasing, widening and thickening of networks in nature and society by van Dijk indicate that networks have become the nervous system of society rather than one that helps to bridge people and society through the application of technology. Second, in view of the first point, even developed countries are not able to develop into a full-fledged network society as advocated by van Dijk.

Our analysis indicates that the content of the network economy as advocated by Castells is nothing more than a rephrasing of the term information economy or knowledge economy as his assertion has been made before by Bell, Porat, Rubin, Nonaka and Takeuchi, among others. This is nothing more than technological determinism (see Webster, 2002a, b, 2004; Garnham, 2004a). Thus, in our view, networks and the network society are nothing new. If there is anything new, it can be perceived as the microelectronics-based, networking technologies that provide new capabilities to an old form of social organization that characterized the industrial society. That is, the network society is viewed as a social economy, and it has very little to do with factors of production or knowledge management.

We analyse the content of the description of the knowledge society advocated by the $\mathrm{UN}$ and UNESCO, and the knowledge-based economy by the OECD. According to Godin (2004, 2006), the writings of the UN, UNESCO and the OECD lack academic rigor and instead they are meant to be rhetoric. Relatedly, Smith (2002, p. 6) indicated that the various terms linked to an economy that is referred to as 'knowledgeintensive' or 'knowledge-based' are used in a superficial and uncritical way as there is no coherent definition, let alone a theoretical concept to explain their differences from one another. UNESCO led us to believe that lifelong learning can be achieved by uniting the community of scientists, researchers, engineers and technicians, research networks and firms involved in the process of research and production of high-tech goods and services, and so doing will integrate into international networks on production, distribution, use and protection of knowledge (Hadad, 2017). From our analysis, the term knowledge society is conveniently coined to tell us that we live in a 'Shangri-La kind of society'. However, the statistical outcome tells another story. Although both bodies (which are under the same umbrella) use the same data and the same statistical technique, they produce different outcomes and these differences reflect different understandings of what the knowledge society is (see Oxley et al., 2007, p. 17), suggesting that the characterization of the knowledge society is flawed.

The term knowledge-based economy is rhetorical (Godin, 2004, p. 680, 2006, p. 19), a metaphor 'often used in a superficial and uncritical way' (Smith, 2002, p.5), and is a buzzword (Godin, 2004, p. 688). To Godin (2004, 2006), the moves by the OECD appear sinister as they led us in falsehood in believing that the new economy is already in existence or is a paradise we ought to aspire. To Sharma et al. (2008, p. 152), the concept of a knowledge-based economy is nothing more than an information economy except that the former is broader as, in addition to technical knowledge, it also includes culture, social and managerial knowledge. The OECD, being a grouping of developed countries, is often a political tool for member governments in promoting familiar proposals around training, skills and infrastructure and sustainable growth coupled with better education 
and wider access to high-speed internet, and yet, the amount of public investment of those activities contemplated is comparatively low (O'Donovan, 2020).

Finally, we evaluate the content of EBRD. The priority areas for EBRD operations and activities are laid out in Article 1 of the institution's founding constitution, which are (1) developing the financial sector through technical assistance to governments and bank officials; (2) supporting the creation of new financial institutions; (3) developing infrastructure, information technology, telecommunications and transportation, improving energy consumption and ensuring a healthy environment; (4) converting the military industry for civilian use; (5) general privatization; (6) restructuring existing industries; and (7) supporting small and medium-sized enterprises (Besley et al., 2020; Shield, 2020). These overlap considerably with the objectives of the IMF and World Bank. Many critiques and NGOs have criticized the EBRD on the lack of progress the Bank makes in its main mission, the 'transition towards open, democratic and progressive market economies'; moreover, they consider some of its funded projects to be environmentally and socially harmful (Neslen, 2015; Bankwatch, 2017). Therefore, the EBRD aims at engaging policymakers and influencing policy debates rather than adopting policies actively provocatively towards a knowledge economy. Moreover, there is a general lack of economy or any theory and relatively little academic analysis of the EBRD, yet it is an institution in the vanguard of development strategies both in and increasingly well beyond Eastern Central Europe (ECE).

We summarize the key commentaries of the knowledge economy as advocated by the precursors of the field in Table 2 .

In our content analysis, we found that all of the 27 key commentators of the first wave of studies on the knowledge economy were critical of the views of the precursors. The works of Machlup, Drucker, Porat and Rubin, and Bell are closely related, but the definition of knowledge (information) by these precursors is so wide that it is anything but knowledge, and an appropriate statistical technique in classifying information and knowledge is wanting. For instance, when describing how knowledge workers use their heads, not hands, in producing goods and services, Drucker also mentioned that these workers should also like to please the boss. And when he wrote about social, political and economic changes of the 'postcapitalist' era of the 'First World Nations', meaning the USA, ordinary citizens become virtually owners of the great American enterprises, i.e. being owners of the capital in overcoming capitalism - an arresting statement that has little to do with the knowledge economy. Nevertheless, in spite of certain inaccuracies, we regard Drucker's works of merit where he did make a number of accurate forecasts, as well as astute perceptions of 1993 that remain true today: (1) the developed countries will be inundated by a human flood of Third World immigrants; (2) in knowledge work and in most service work, the machine (if any) is a servant to the worker; (3) a severe problem is the diversion of the scarcest resources - trained engineers and scientists to economically unproductive defence work - the malefactor being the USA where over $70 \%$ of all money spent on R\&D is spent on defence work (affirm by Phillips et al., 2017); and (4) knowledge, knowledge workers and technological progress determine quality of products - the case of Japan being the first non-Western nation in modern times to become a great economic power. According to Drucker (1993), the winners in this new economy will be those who master knowledge about knowledge. 


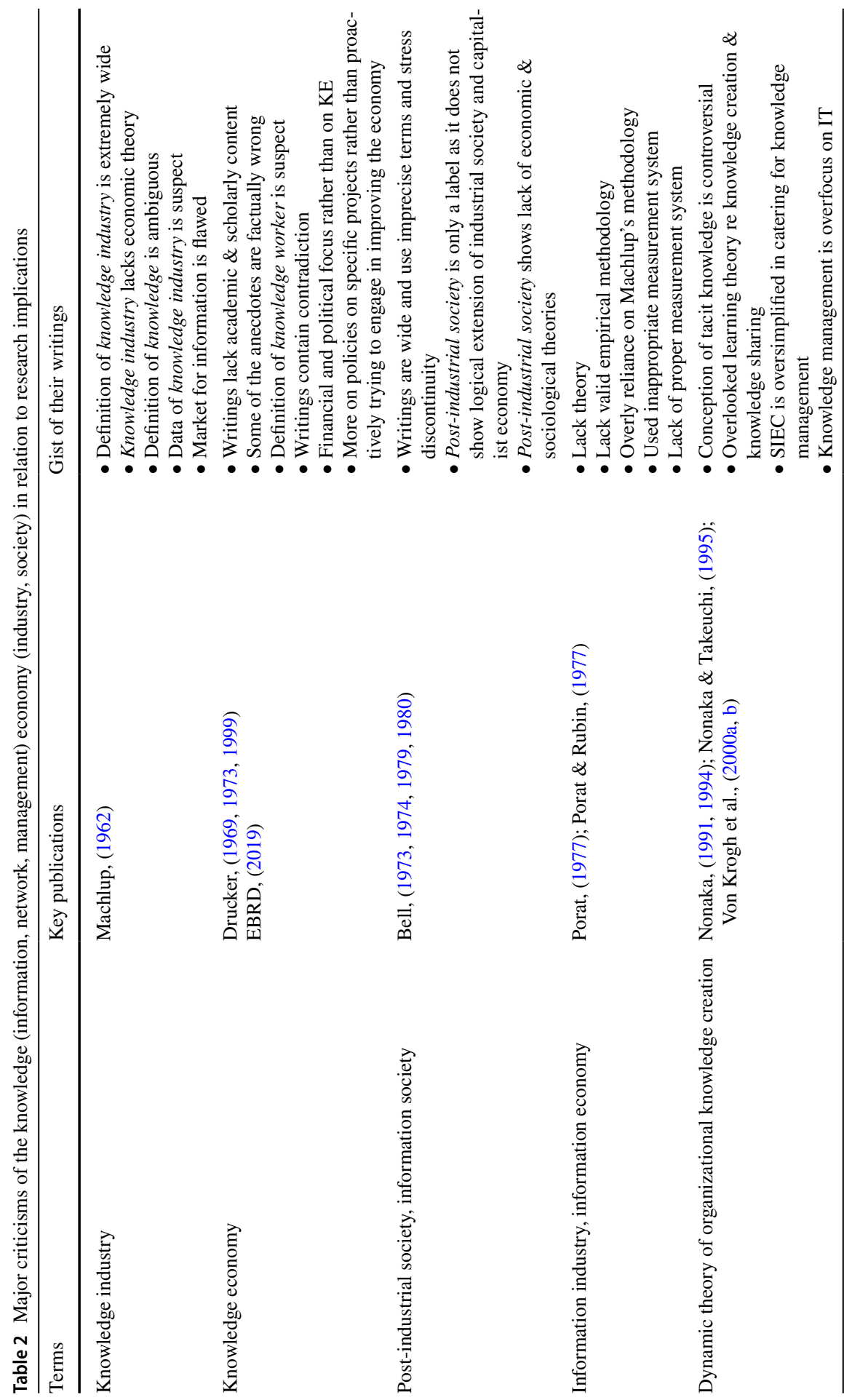




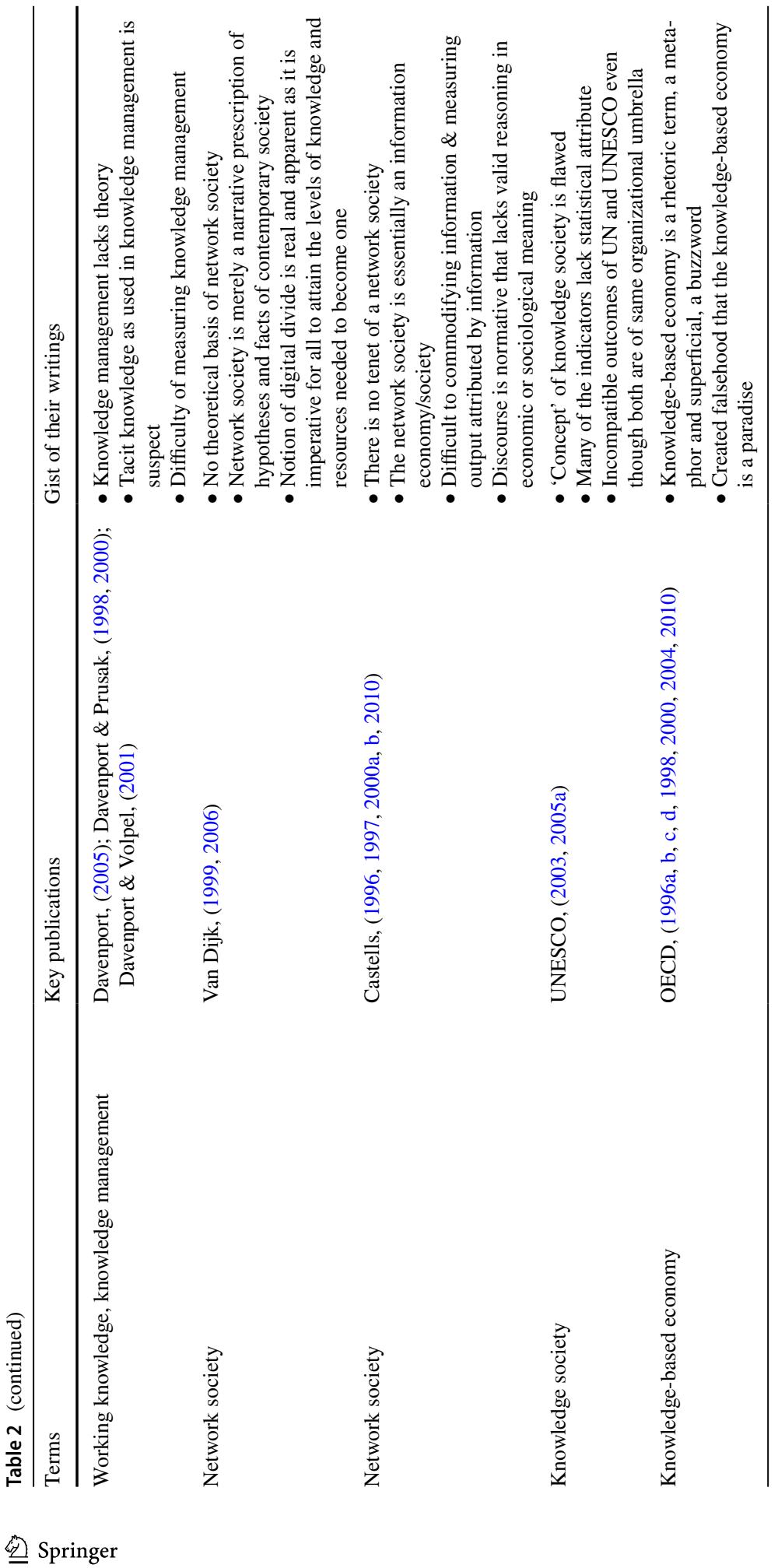


Of the 33 key commentaries of the second wave, only the works of Nonaka and Takeuchi received some favourable commentaries, and in fact, their notable work on the SECI framework has been embraced by notable researchers. We consider that Nonaka and Takeuchi had initiated a difficult paradigm of articulating tacit knowledge in the conception of knowledge in knowledge creation (management) where, if properly transferred (applied) among knowledge workers, it would lead to the sustaining of competitive advantage of firms and the collective effort of firms would enable the country to prosper in the future. On the contrary, the network society expounded by van Dijk and Castells is nothing more than a mere extension of the information economy. Third, we rule out the writings of the UN, UNESCO, OECD and EBRD to be scholarly and worthy of research consideration as they not only lack academic rigor but also meant to be rhetoric or myths. Moreover, we see they serve certain government policies and political agendas that are geared towards the West, particularly the OECD and the EBRD.

We feel that one particular crucial aspect both the first and second waves of studies of the knowledge economy have missed out is health matter-to build a strong and progressive society/economy, there must be in place a good health system to take care of not only knowledge workers but also the population in general. Investment in health is not only desirable; it is an essential priority for most societies. This is especially so in view of the current Covid-19 pandemic. Healthcare performance is strongly dependent not only on the economy but also on the health systems themselves: all these are essential to a healthy society (Eissa, 2020).

\section{Theoretical Consideration in Advancing the Research on the Knowledge Economy}

\section{Seeking Common Ground in the Furtherance of the Research of the Knowledge Economy}

Despite the various issues surrounding the works of the knowledge economy, there are commonalities of thoughts and propositions among the precursors, suggesting that there is a common ground for us to establish some theoretical foundations of the field. First, we need to rationalize whether the terms economy and society have any significant difference in meaning. The relationship between economy and society and how it is determined is a matter of theoretical debate. The classical economists (including Emile Durkheim, 1858-1917; and Max Weber, 1864-1920) have articulated a new form of the economy (at their time) in a way where people envisage is probable. Durkheim viewed the economy as one of the numbers of social institutions that make up a society, and Weber viewed the economy in part as an extension of social values and religious belief. Therefore, the economy and society are inextricably linked.

Second, in our critical analysis, we realize that the differences in terms used by the precursors of the knowledge economy are partly due to the time factor because the stages of the economy change with time. In the industrial economy, an old economic dictum of Adam Smith (1723-1790) existed from the eighteenth 
century in which agricultural products and mass-produced manufactured goods were the key components of the economy, and the majority of workers were farmers, clerks or machinists. The post-industrial economy (information society) is the period from the late 1960s where mass production from the developed countries shifted to developing countries, and the mainstay of economic activities of the developed countries is services supported by technology (mainly computerization) and changes of society (social values).

Nonaka, Takeuchi, Davenport, Krogh, Prusak and Volpel focus on knowledge on the organizational level, i.e. knowledge management, which when aggregated among firms would contribute to the notion of the knowledge economy. This period is around mid1990s. Despite critiques claiming that there is no difference between an information economy and a knowledge economy, we argue that knowledge is more than information because knowledge is being creative and innovative (i.e. it uses information to make things different from others), thus giving us a competitive advantage. That is, the use of knowledge is increasingly of a greater magnitude and importance in a knowledge economy era (Houghton \& Sheehan, 2000; Giddens, 2001; Powell \& Snellman, 2004; Roberts, 2010; Garza-Rodriguez et al., 2020). In a study conducted for Mexico, the results show that the impact of human capital on economic growth is almost three times greater than that of physical capital (Garza-Rodriguez et al., 2020). Notice that none of the precursors emphasize on production and consumption. The various stages of economic (societal) development are depicted in Fig. 1.

Figure 1 shows the evolution of the economies (societies) from the pre-industrial to industrial stage and finally to the post-industrial stage. In the post-industrial stage, three variations of economies/societies are envisaged. The information economy (society) is the progression from the industrial economy (society). While there is a progression from the information to knowledge economy, the path of the network society is difficult to envisage as it appears that it is in a stage of a continuum but

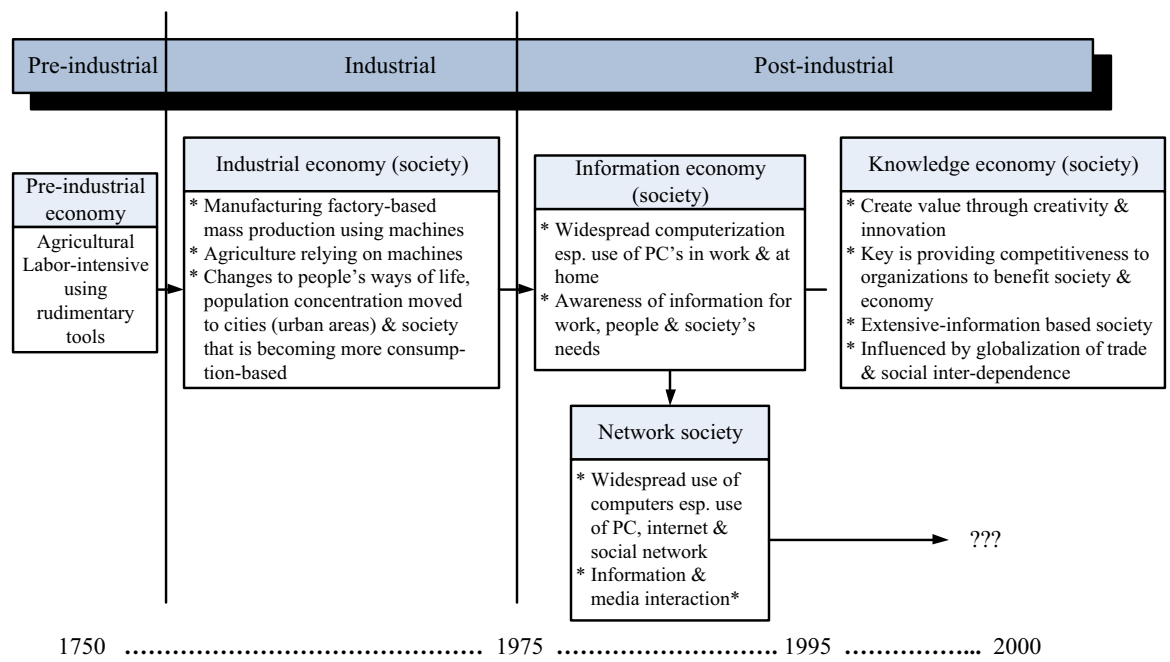

Fig. 1 Stages of economic and social development 
where it is heading is unknown. It does not mean that once a country/society has attained a high amount of ICT expenditure or economic development, it can be considered a knowledge economy. Take the case of Hong Kong, HK (China), many of its residents and $\mathrm{HK}$ specialists regard $\mathrm{HK}$ as a knowledge economy, but in actual fact $\mathrm{HK}$ is predominately a service economy rather than a capital-intensive technologically advanced economy. Zhu and Chou (2020) indicate that although HK has made improvements in knowledge-induced productivity from 1991 to 2011, it still has some ways to go to meet the requirements of a knowledge economy. There is still an economic gap between occupations that are knowledge-intensive and knowledge-non-intensive, and there are overeducated employees who find themselves unemployable. Unless these deficiencies are addressed, transforming HK's economy from a service economy to a knowledge economy appears unattainable.

What is more important is that, from the study of the various precursors' works, we are now getting nearer in understanding this new kind of economy, i.e. by finding a common ground to show how a society becomes a knowledge economy:

- We estimate the starting point of the knowledge economy to be mid-1990s.

- There is no difference whether the new economy is viewed as an economy or society.

- The knowledge economy is not really an economy based solely on production and consumption by exploiting labour and capital, but it is based more on a social value and structure.

- Extensive use of technology and the ability for us to exploit them for commercial reasons and for personal and organizational enjoyment (i.e. sociability or societal benefits).

- Extensive use of innovation to commercialize knowledge (knowledge creation, knowledge management)

\section{Theoretical Framework of the Knowledge Economy and Its Usefulness for Future Research}

The discussion from the previous subsection provides us with the theoretical foundation needed to define a knowledge economy (see Fig. 2).

In Fig. 2, the knowledge economy consists of sociability, technology, knowledge and innovation, and knowledge products.

The authors/articles who have contributed to our foundation of the Knowledge Economy/Society are presented in Table 3:

Our discussion of the sub-header will be made in conjunction with Fig. 2 and Table 3.

\section{Social Economy}

In our critical analysis, we found that the knowledge economy is not an allencompassing economy as it cannot address (all) the various aspects of technology, innovation and organizational and people's needs. Moreover, the knowledge 


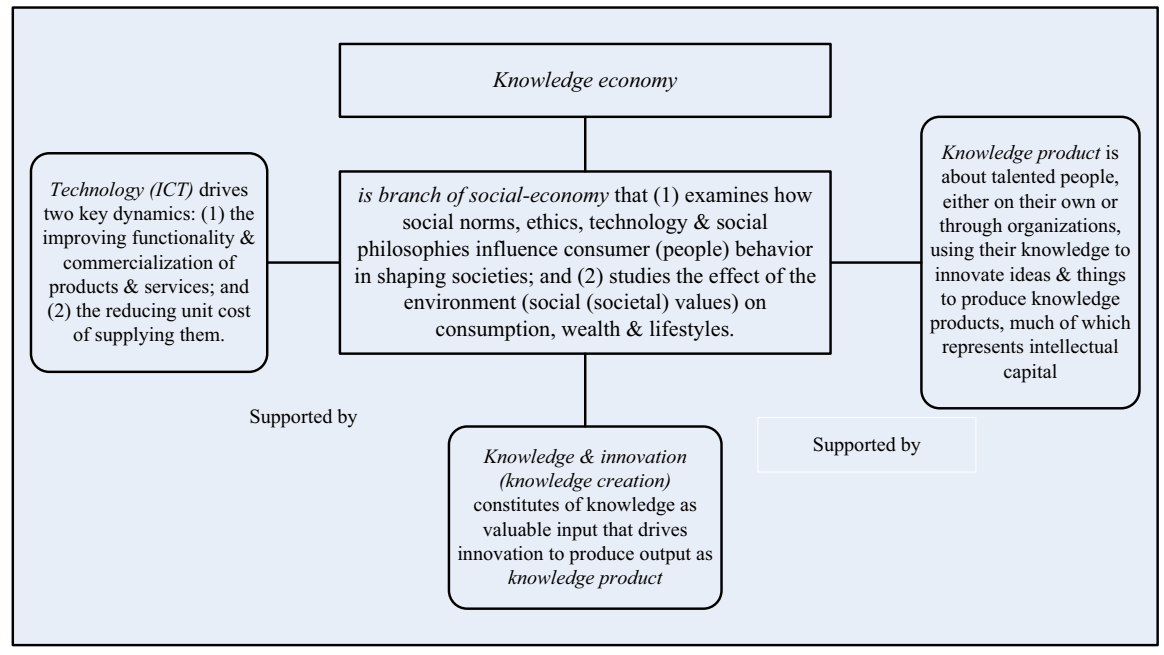

Fig. 2 Suggested key aspects of the knowledge economy that may be considered as the common ground in researching the field

economy lacks a theory. In our search for solutions, we found that this kind of economy that can offer us with good explanations of the radical change in the ways people think and expect in a society, and how organizations (institutions) are utilizing innovation by tapping the power of technology in creating knowledge products in the furtherance of the economic well-being of a society (country), is viewed in terms of the social economy.

We found that the idea of the social economy has attracted researchers, governments and non-government agencies especially in continental Europe and Canada (Gueslin, 1987; Demoustier, 2004; Moulaert \& Ailenei, 2005). According to these writers, the social economy apparently arises through the progression of time, and its theoretical foundation can only be analysed by combining a 'history of practice' with 'a history of thought perspective'. The nineteenth century ought to be taken as the formative era of the modern social economy as it was characterized by an outburst of ideas, concepts and experiences; cooperative, associative and social awareness; institutional and utopian initiatives and the emergence of social, economic and political liberal philosophies in reaction to the social brutalities (poverty and exploitation), and political indifference (lack of social welfare) of the Industrial Revolution. This assertion is also shared by Le 'vesque et al. (2001; cited in Moulaert \& Ailenei, 2005).

These writers also asserted that the theoretical arguments tend to be recurrent, and that the social economy is not an economic system on its own as there are diverse views of the foundation of this kind of economy. The diverse views may create a magnitude of possible theoretical foundations of what constitutes a knowledge economy. Because of these, it is exceedingly difficult, and probably not scientifically useful, to reconcile the wide world of initiatives and activities connected to the social economy in a 'one for all' definition (Moulaert \& Ailenei, 2005). 


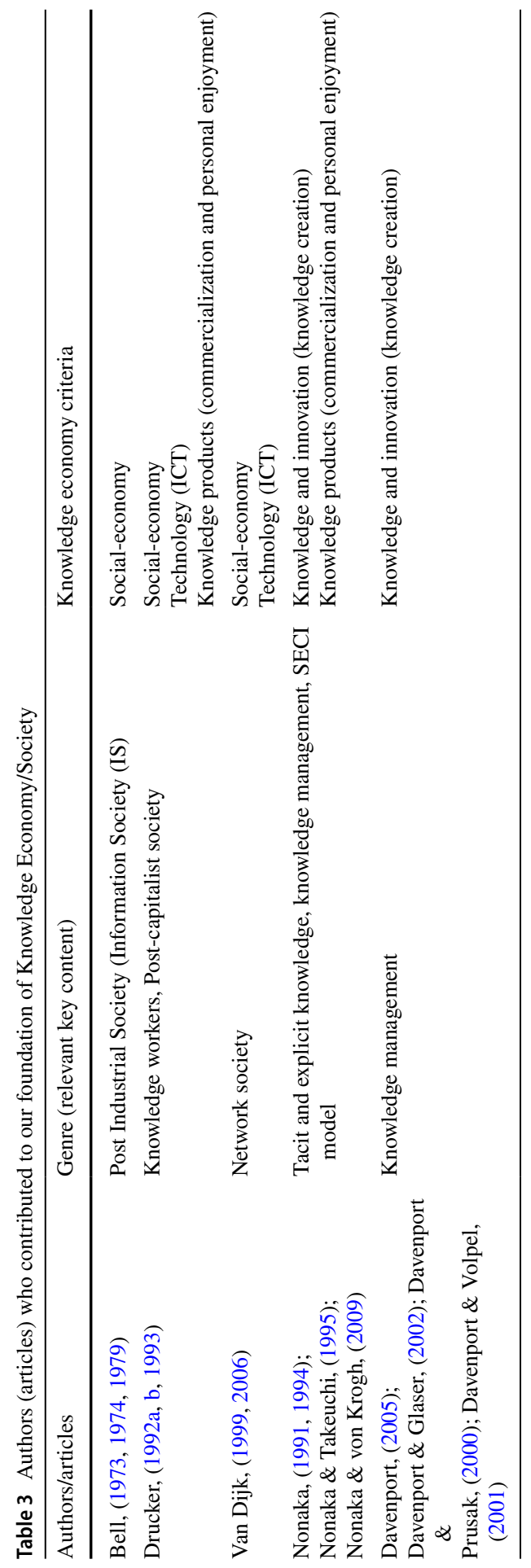


In our content and critical analyses, we find that one social thesis that takes into consideration personal needs is the one that has been put forward by the international philosopher, author, poet, composer and linguist, P.R. Sarker (1921-1990). A series of lectures were published in 1959 as Idea and Ideology, where Sarkar described a socioeconomic theory which he called Progressive Utilization Theory (PROUT) (Sarkar, 1959). The PROUT is based on progress, philosophy of life, spiritual belief and utilization of the qualities of practical education (as against academic education), morality and socioeconomic consciousness in an economy in order to provide a good standard of living to all people and to see that economic power is not concentrated in the hands of a few.

In some ways, PROUT philosophy is akin to Drucker's (1993) Post-Capitalist Society, Bell's (1973) Post-Industrial Society or van Dijk's (1999) Network Society in which developed societies that have exploited IT successfully will be able to transform from an agricultural economy to knowledge economy-towards a utilization society where there is a good standard of living to all people and to see that economic power is not concentrated in the hands of a few. Bell asserted that his thesis is about the attainment of an industrialized society and is not universal as it relates only to the USA while Drucker's thesis applies only to developed countries such as the USA, Western Europe and Japan, and van Dijk considers that all countries are capable of attaining the network society status if they have successfully utilized IT. Except for van Dijk, the various KE writers are rather biased as they see that only the USA, Western Europe and Japan can become advanced economies. Little did they realise that South Korea, Taiwan (China) and soon China would become advanced technological countries.

It is true that the USA, Western Europe and Japan are wealthier countries than some of the developing countries, and so they can invest in a variety of things notably in health care. For instance, the USA devotes more of its national income to healthcare relative to other OECD countries where the OECD averaged about $8.7 \%$ of annual GDP; healthcare spending in the USA, however, stood at $17 \%$ while the rest of OECD countries range between 9.0\% (Spain) to 12.1\% (Switzerland) at 2019 (World Bank, 2020). This compares with 5.08\% (Sub-Saharan countries), $7.96 \%$ (Latin American \& Caribbean countries), 3.48\% (South Asian countries), and $6.67 \%$ (East Asian \& Pacific countries) (World Bank, 2020). Higher healthcare spending can be beneficial if it results in better health outcomes. But looking at the statistics, surely the USA and OECD countries would have spent much more on health and the outcomes ought to outperform developing countries. However, this is not the case. In view of the Covid-19 pandemic, the USA and developed countries fare worse than some developing countries notably East Asian countries like China, Taiwan (China), Vietnam and Thailand. High administration costs including salaries of medical professionals and high medicine costs are among the reasons cited why the USA and OECD countries have higher healthcare expenses in relation to developing countries (Peterson Foundation, 2020). Moreover, pandemic preparedness and response capacity of these countries are less efficient compared with the East Asian countries. Pandemic preparedness is not a new concept as several pandemics have occurred before. For instance, China and Vietnam can plan, mobilize and utilize resources and deploy emergency assets in quick time and they can treat and monitor patients on a sustainability basis. A healthcare system with high costs, inadequate preparedness 
and response and poor outcomes undermines our economy and threatens our longterm fiscal and economic well-being. Indeed, the recent pandemic has given a basic message: investments in health and the design of health financing policies should be addressed in terms of the interaction between health and the economy (Eissa, 2020). Just as growth, income, wealth, investment and employment are a function of the performance and quality of the economic system, its regulatory frameworks, trade and political policies, social capital and labour markets, etc., so health conditions (mortality, morbidity, disability, ability to confront pandemic) depend not just on standards of living but on the actual performance of health systems themselves.

Our analyses also reveal other useful findings. In an extensive study of the social economy of Canada, and in particular, Quebec, Ninacs and Toye (2002) articulated that the social economy is not an entirely new type of economy, consistent to the contention of Gueslin (1987), Demoustier (2004) and Moulaert and Ailenei (2005). Instead, Ninacs \& Toye argued that the 'newness' related to the evolution of the social economy over the past 35 years or so is due to the presence of new types of people who become promoters or members, new stakeholders, new fields of activity, new organizational forms and new internal and external dynamics. Although many aspects of Ninacs and Toye's (2002) arguments relate to knowledge and innovation, the indicated timeframe of the social economy evolution, which was supposed to arise in 1965, was a bit far-fetched from our posited period (mid-1990) of the formative years of the knowledge economy.

We found Brown's (2008) work on the social economy relevant. Drawing on a wide range of writings on the social economy, Brown (2008) finds it useful to think of the theoretical foundation of the social economy in the following ways: (1) it is a branch of the economy that is concerned with the relationship between social behaviour, people well-being and economies, and (2) it is not an unorthodox school of economies (e.g. classical or neo-classical theories) and often takes into account subject matters outside the focus of orthodox economic theories. Thus, the social economy encourages people and society to utilize resources to satisfy human and community needs, including humanity, changes of educational and economic development, promotion of thinking and innovation in which human and society can collectively earn their minimum necessities through appropriate work in producing knowledge products. This economic system can be regarded as the organizational arrangement and process through which a society makes its production and consumption decisions which society deems desirable, like efficiency, growth, liberty and equality, consistent with what Conklin (1991) had advocated earlier.

In a similar vein, Nasioulasa and Marisb (2011) indicated that the social economy enhances the promotions of social cohesion, innovative entrepreneurship and employment with the help of digital and network technologies, thus sustaining an economy with a rising social need and the demand for uninhibited access to digital content throughout the cyberspace. This invariably is mainly orientated towards the use of computer technology for the creation of knowledge products. Knowledge products require innovation, and the importance of innovation is even more important in recent years as many markets have become mature, and many mature companies have failed to survive as they fail to capitalize on the exploitation of technology to innovate their products (see Lynch \& Jin, 2016). 
Therefore, in our view, we rule out PROUT to have much relevance to the knowledge economy as the first is too political with a heavy emphasis on the equilibrium of social needs and social and spiritual well-being. We consider that the knowledge economy is a branch of the social economy (as in Brown, 2008) (see also in Gueslin, 1987; Demoustier, 2004; Moulaert \& Ailenei, 2005; Nasioulasa \& Marisb, 2011) that is tied to social innovation, reliance on knowledge and technology and use of new types of production in churning out knowledge products or exploiting new markets that bring it into the realm of economic innovation. This is brought about by social entrepreneurs (innovators) working in social organizations where these entrepreneurs combine creativity with pragmatic skills in pioneering new solutions to social problems and in doing so change the patterns of society. Thus, the knowledge economy is a social change theory, much akin to Lewin's contemporary social organization and management change model (see Huarng \& Mas-Tur, 2016).

\section{Technology (ICT)}

In our content and critical analyses, this new kind of economy is made possible through the explosion and exploitation of technology, in particular ICT which begins from the mid-1990s, largely due to the emergence of the dot.com's. From our review of the studies of the precursors of the knowledge economy, technology drives two key dynamics: (1) the improving functionality and commercialization of products and services and (2) the reducing unit cost of supplying them. Industry-wide progress clearly gives rise to products that would not have been possible just a few years earlier, and at increasingly affordable prices. Adapting to technological progress is important because the knowledge economy is a continuously adapting field between the public and private sectors, individuals and organizations in which there exists a rising social need and demand for uninhibited access to ICT especially semantic web and digital content throughout the cyberspace. The development of technology allows organizations and the public in benefitting not only from participating to the availability of many new commercial software but, more importantly, from sharing data and their interpretation of information (Robinson \& Bauer, 2011). This includes innovative modalities among content, user and transit such as peer-to-peer networks that have substantially enhanced digital content delivery (Nasioulasa \& Marisb, 2011). In Australia, the introduction of the national curriculum in 2013 places high emphasis on the integration of digital technologies throughout key learning areas. There are pedagogical justifications for using ICT across the key learning areas as young children must be made exposed to ICT literacy as it is clear that children learn to use technological devices very quickly (ICTE, 2020).

We found that Drucker's integrative thinking illuminates the special obligations imposed by technology on modern business organizations. From witnessing the early development of technology in industry, Drucker noticed that in organizations, management and society there has been a massive overall change in the nature of technological work during our century - a change in its structure, costs, methods and conceptual underpinnings. 
We can connect that the rise of the information society will see the emergence of a network society in which information, computer and technology will enable the formation of networks among users. Essentially, the network society, as Van Dijk sees it, can explain a new type of society where social relations are organised within mediative technologies that form a communication network rather than networks typified by face-to-face social relations. The network is developed in a society that allows for a great deal of information to be processed, exchanged and disseminated to help improve information and communication technologies - that is, it facilitates the globalization of IT.

The technological capability must be harnessed at both the micro and macro levels (Berners-Lee, 2010). For example, firms use serious games (i.e. video games used in a professional context) to make training more exciting and immersive as they take players into virtual worlds where they learn and experience real-world scenarios in a funny and entertaining way (Allal-Chérif \& Makhlouf, 2016). On the macro level, we argue that technological innovation and ICT represent a way for knowledge economic countries to foster economic development, exploit technology (ICT), improve levels of education and training and address social (societal) issues within a knowledge economy, a view similar to OECD (2015).

Technology prowess does not stem from high ICT spending. High ICT spending by a country may have poor IT utilization, as seen in the case of high health spending which may have low health outcome. Following years of growth, ICT spending will remain relatively flat in 2020 due to the COVID-19 pandemic, and in the next 5 years, all growth in traditional tech spending will be driven by just four platforms: cloud, mobile, social and big data/analytics (ZDNet, 2020). For instance, Singapore has been spending heavily on ICT for the past years and the government plans to increase its ICT spend by 30\% in its fiscal 2020 (ZDNet, 2020). However, Singapore is not considered a knowledge economy because most of its technology comes from abroad. Wang (2018) found that over 70\% of Singapore's private sector R\&D expenditure and the bulk of industry patents came from foreign multi-nationals, and there is evidence that innovation is government 'push'. Moreover, she is ill-equipped to handle and maintain technology as seen on 14 October 2020, when a damaged power cable led to a series of events that caused a major subway (MRT) disruption affecting three train lines - an incident which transport experts said could have been avoided (Straits Times, 2020 Dec 16).

\section{Knowledge and Innovation (Knowledge Creation)}

We argue that the rise of the interest in the knowledge economy has meant that economists have been challenged to look beyond labour and capital as the central factors of production. More recently, Aghion et al. (2004) have indicated that innovation (knowledge creation) in inducing competitiveness among organizations is considered a third important factor of production. In today's complex, competitive and turbulent environment, the need for innovation in products and processes is widely recognized and organizations are required to apply new technologies and to innovate timely in anticipation of changes in the marketplace rather than as a reaction to business decline (Rahimi, 2017). Although knowledge and innovation have been widely discussed by the precursors of the 
second wave of studies on the knowledge economy, there are gaps in their articulation, viz. on how knowledge and innovation can help in transforming an economy to one that is based on knowledge. We will now explain this.

We consider thatknowledge is a valuable input that drives innovation, and the output is knowledge product. Knowledge products will be discussed in the next subsection. In between input and output is knowledge management. Nonaka (1991) described tacit knowledge as the fuel for innovation but was concerned that many managers failed to understand how knowledge could be leveraged. Organizations are more like living organisms than machines, he argued, and most viewed knowledge as a static input to the corporate machine. Nonaka advocated a view of knowledge as a dynamic mechanism - renewable and changing - and that knowledge workers were the agents for that change. Nonaka and Takeuchi then forwarded the argument that creating knowledge will become the key to sustaining a competitive advantage for organizations in the future. As the competitive environment and customer preferences changes constantly, knowledge perishes quickly and therefore managers and knowledge workers must rejuvenate it. In addition, Nonaka and Takeuchi show that, to create knowledge, the best management style is neither top-down nor bottom-up, but rather what they call 'middle-up-down' in which the middle managers form a bridge between the ideals of top management and the chaotic realities of the frontline workers. Thus, knowledge-creating companies, Nonaka and Takeuchi believed, should be focused primarily on the task of innovation.

Innovation can be attributed to various sources, and innovative processes usually involve identifying customer needs, macro and micro trends, developing competencies and finding financial support in order to sell the innovation-a strong motivation for the commercialization, or value creation of knowledge. Businesses must engage customers to develop products that sell. Interestingly, more recently, the casual claim between customers and innovations have been reversed in which customers are the ones that are important in the development of new innovations for commercial purposes (see Lettl et al., 2006; Desouza et al., 2008; Oberg, 2010). The innovation process ends upon the successful transformation of knowledge to innovation, resulting in the creation of value enhancement intellectual capital (IC), or intangible assets (IA) as called in accounting, which can generate future benefits to organizations (see Choong, 2008; Lages, 2016).

\section{Knowledge Products (Commercialization and for Personal Enjoyment)}

So what actually are knowledge products? The literature indicates a wide range of activities that can constitute knowledge products such as skills, knowledge, know-how, work-related experience, competencies, education, creativity, brand, trademarks, intellectual property (IP), copyrights, trade secrets, work procedures and software, among others. We found that these products are no different from the products of the old economy. There is no clear definition. Drucker attempted to describe knowledge product in a protracted manner. Knowledge workers put knowledge to work and that information is not knowledge. Information must be applied to specific work, and there must have improved performance for it to be classified as knowledge. Drucker emphasized that only human beings with their 
brains and/or the skill of their hands can convert information into knowledge. The outcome of which the products so developed are new-i.e., newness determines a product to be knowledge product.

As Nonaka and Takeuchi pointed out, 'understanding how organisations create new products ... is important. A more fundamental need is to understand how organisations create new knowledge that makes such creations possible.' Given in today's competitive market, technological changes, customer demands and revolutionary technologies combine to place pressure on organizations to constantly innovate and provide cutting-edge outcomes. Nonaka, Takeuchi, Davenport and Völpel have indicated that the key is innovation and developing innovative capabilities such as architectural innovation capability enhances firms' ability to respond to market demands by producing innovative products and services and can has a profound impact on their performance.

For us, knowledge products differ from other kinds of products in that their relevant and useful aspects reside primarily in the content that can be extracted from them, and as such, any physical manifestation thereof is usually at best a carrier medium. It is about talented people, either on their own or through organizations, on how they use their knowledge to innovate ideas to produce knowledge products. Also, they must have appeal so that the products can be commercialized. Thus, the creation of knowledge products creates social benefits to people, organizations and society. From these explanations, we rule out knowledge work (jobs), such as skills, know-how, work-related experience, competencies, education nad work procedures, to be knowledge products.

From the literature and our analysis, knowledge products are indeed difficult to define. Hence, we use an illustration to explain what exactly knowledge product is. Take the case of a mystery killer storybook written by an author. The book is a physical item, not a knowledge product, and the knowledge product is the intriguing story of the book, which is the research, innovative and artistic outcome arising from the tacit and explicit knowledge of the author, which are required to make it different from another story. Similarly, let us take a look at the music, dance and song of Billie Jean by Michael Jackson. The CD is a physical item, not a knowledge product, and the music, dance, expression and choreography, collectively, are the actual knowledge product. From these two examples, we explain that the physical element and the intellectual element must be differentiated or else there is no clear boundary between a tangible and intangible item. It can be seen that an intangible item cannot exist on its own right. In fact, both tangible and intangible items are complimentary of each other in the form of a knowledge product. Blended together, they create values and bring competitive advantage to the developers (talented people) and organizations. More importantly, the creation of knowledge products necessitates innovation and knowledge sharing, and the commercial outcome is benefits to people and organizations that use them, i.e. a social-economic perspective. More specifically, Muriel and Serrat (2009) and Rooney et al. (2012) have described knowledge products as the outcome of the production of knowledge, much of which represents intellectual capital. 
There is no data for knowledge products by country. The closest data we obtained is data for high-technology exports in current prices published by Knoema which compiles data for the world and country level from sources such as the World Bank, IMF and OECD. Knoema defines high-technology products as products with high R\&D intensity, such as in aerospace, computers, pharmaceuticals, scientific instruments and electrical machinery. In 2019, Knoema ranks HK (China) to be the largest exporter of high-tech products, follow by Germany and the USA. Mexico is placed seventh and Belgium is placed eight. China, which is recognized as a factory for high-tech products, is not represented in the list which consists of 43 countries. Comoros, a country consisting of several tiny islands with less than a million people off the coast of Mozambique (East Africa), is ranked 43rd in terms of largest export of high-tech products. Ironically, HK (China) and to a lesser extend Mexico and Belgium are not really into manufacture of knowledge products. Surely, Comoros is not into high-tech knowledge products. Therefore, reliance on published statistics is misleading as seen in the case of health care and technology prowess.

The framework of the knowledge economy and the statistical assessment methodology proxied by the four proxies are as shown in Table 4.

\section{'Apparent' Knowledge Economy Countries}

This is the ultimate work with respect to this research, as there is no precedence or methodology concerning how countries can be construed to be knowledge economies. What is important is to establish the statistical assessment methodology

Table 4 The framework of the knowledge economy and the statistical assessment methodology proxied by the four proxies

\begin{tabular}{|c|c|}
\hline Proxies (indicators) & Knowledge economy criteria \\
\hline $\begin{array}{l}\text { Social progress } \\
\text { The Index measures social progress using } 53 \text { indicators across areas } \\
\text { including personal safety, environmental quality, personal freedom and } \\
\text { choice, nutrition and basic medical care }\end{array}$ & Social economy \\
\hline $\begin{array}{l}\text { IT usage } \\
\text { Based on communications and connections (esp. the Internet), IT usage, } \\
\text { facilities, usage of computers/IT tools from the government needed to } \\
\text { promote good lifestyle and requirements of society to enjoy their life. } \\
\text { The ranking is based on individual usage, business usage \& government } \\
\text { usage }\end{array}$ & Technology (ICT) \\
\hline $\begin{array}{l}\text { Innovation } \\
\text { Based on investments in } R \& D \text { and innovation, innovation quality, output } \\
\text { and efficiency. All these are central to economic growth; helping devel- } \\
\text { oped countries reinvent themselves in times of economic decline and } \\
\text { emerging countries answer their societies' growing needs }\end{array}$ & Knowledge and innovation \\
\hline $\begin{array}{l}\text { IP grant and trademark application } \\
\text { Rankings are based on the total numbers of applications of patents, } \\
\text { trademarks and designs filed by origin, and three rankings will be used } \\
\text { in respective order }\end{array}$ & Knowledge products \\
\hline
\end{tabular}


for the level of knowledge economy against other type of economies (Rim et al., 2019). They hypothesize the indicators come from two sources: (1) economic growth and the expressions of knowledge-based economy and (2) the statistical assessment methodology for the level of knowledge-based economy based on the first part. From this, we articulate one approach in which proxies (indicators) can be used to measure the four knowledge economy criteria we have thoroughly expounded earlier. They are (1) social economy; (2) technological strength; (3) knowledge \& innovation; and (4) knowledge products.

We make use of per capita GDP (nominal) ranking of selected countries in ascertaining how well they relate to these four criteria (see Table 4). Some readers may argue on why we did not use GDP based on a PPP basis. We find that the PPP basis consists of too many consistencies as (1) the purchasing power is subjective; (2) the metrics used were not thorough researched; and (3) the purchasing power tends to give a high value to certain countries. We based our analysis on the selected 18 countries because it is beyond the scope of this paper to list every possible country in ascertaining whether or not they satisfy the criteria of the knowledge economy. We proxied social economy with social progress index produced by Social Progress Imperative, USA. Social progress is defined as 'the capacity of a society to meet the basic human needs of its citizens, establish the building blocks that allow citizens and communities to enhance and sustain the quality of their lives, and create the conditions for all individuals to reach their full potential.' (Institute for Strategy and Competitiveness, 2020) Technology (ICT) is proxied by the Technology Strength Index which consists of four integrated metrics, three of which serve as standard measures of the availability and prevalence of technology: (1) internet users as a proportion of the population; (2) smartphone users as a percentage of the population; and (3) LTE users as a percentage of the population. The fourth metric we used is a Digital Competitiveness score developed by the IMD World Competitiveness Center. Their competitiveness score focuses on technological knowledge, readiness for developing new technologies, and the ability to exploit and build on new innovations (Global Finance, 2020). Knowledge and Innovation are proxied by the Innovation Index, published by the World Intellectual Property Organization (WIPO, 2020) and as data is not available for Taiwan (China), we use Innovation Index taken from Bloomberg, NY, USA. It ranks 60 countries in terms of its ability to innovate its products and services (Bloomberg, 2020). Knowledge products are products created by knowledge or intellectual capital, and they are at the stage ready to be commercialized for personal enjoyment. They are proxied by two indexes: Patents granted and Trademarks in force. The indexes are published by the World Intellectual Property Organization (WIPO, 2020), Geneva, Switzerland. These indexes are by no means the best, but they are readily available. For instance, Tech-strength Index and the Innovation Index ranked certain countries far too high and certain countries too low. For instance, for Tech-Strength Index, Singapore is ranked eight, way ahead of Germany and South Korea and for Innovation Index, and UAE is ranked eight against powerhouse Japan and Taiwan (China). 
We agree that other approaches or methodologies and other proxies may be used in ascertaining a knowledge economy, and this is an interesting avenue to explore. The selected countries illustrating knowledge economies are tabulated used for in Table 5 .

Although Qatar has the high per-capita GDP, it does not meet many of the requirements of a social economy (fail to satisfy most of the four elements) and so we exclude it for our analysis. We also exclude some other high-income countries/ jurisdictions such as Macau (China), Ireland, Brunei, Kuwait, Bahamas, Malta and San Marino because of its small population. While Hong Kong (China), Singapore, Ireland and Iceland have high income and sufficiently high human capital, they lack knowledge and innovation to generate their own knowledge products, and hence they are not selected for consideration of knowledge economies. Oman, Spain, New Zealand, Poland and Hungary may have fairly high technology usage, but most of their knowledge products are imported. Russia and China are not high-income countries but are included for comparison purposes because of their strength in generating knowledge products. Although the USA has high GDP and certain good

Table 5 The selected countries and their associated indexes that proxied the elements of knowledge economy

\begin{tabular}{|c|c|c|c|c|c|c|c|c|c|c|c|c|c|}
\hline \multirow[t]{2}{*}{ Rank } & \multirow[t]{2}{*}{ Country } & \multicolumn{2}{|c|}{ GDP per capita } & \multicolumn{2}{|c|}{$\begin{array}{l}\text { Social } \\
\text { progress }\end{array}$} & \multicolumn{2}{|c|}{$\begin{array}{l}\text { Tech } \\
\text { Strength }\end{array}$} & \multicolumn{2}{|c|}{ Innovation } & \multicolumn{2}{|c|}{ Patents grant } & \multicolumn{2}{|c|}{$\begin{array}{l}\text { Trademarks in } \\
\text { force }\end{array}$} \\
\hline & & Rank & Value & Rank & Value & Rank & Value 1 & Rank & Value & Rank & Value & Ran & Value \\
\hline 1 & Luxeml & 1 & 109,602 & 14 & 89.56 & 16 & 3.4 & 18 & 50.84 & - & 326 & - & - \\
\hline 2 & \$ Switzerland & 2 & 81,867 & 5 & 91.42 & 11 & 3.55 & 1 & 66.08 & - & 1,751 & 21 & 94,477 \\
\hline 3 & Denmark & 7 & 58,349 & 2 & 92.11 & 4 & 3.67 & 6 & 57.53 & - & 615 & 25 & 68,705 \\
\hline 4 & Australia & 10 & 51,885 & 8 & 91.29 & 15 & 3.4 & 23 & 48.34 & 9 & 17,010 & 18 & 119,932 \\
\hline 5 & Netherlands & 11 & 51,290 & 10 & 91.06 & 3 & 3.67 & 5 & 58.76 & - & 1,936 & - & - \\
\hline 6 & 틀 Sweden & 12 & 50,339 & 5 & 91.62 & 2 & 3.68 & 2 & 62.47 & - & 920 & - & 17,330 \\
\hline 7 & Fimana & 14 & 48,461 & 21 & 87.88 & 7 & 3.40 & 7 & 57.02 & - & 505 & - & 8,234 \\
\hline 8 & Germany & 15 & 45,466 & 11 & 90.56 & 19 & 3.33 & 9 & 56.55 & 8 & 18,255 & 12 & 173,410 \\
\hline 9 & $\|+\mathbb{C}$ Canada & 17 & 42,080 & 7 & 91.40 & 14 & 3.47 & 17 & 52.26 & 7 & 22,009 & 14 & 157,397 \\
\hline 10 & $\overline{\underline{6}}$ Israel & 19 & 41,560 & 33 & 83.62 & 29 & 3.13 & 13 & 53.55 & 18 & 4,197 & - & 25,306 \\
\hline 11 & France & 20 & 39,257 & 18 & 88.78 & 22 & 3.27 & 12 & 53.66 & 10 & 13,598 & 4 & 292,520 \\
\hline 12 & United Kingdom & 21 & 39,229 & 20 & 88.54 & 12 & 3.49 & 4 & 59.68 & 17 & 5,948 & 7 & 205,337 \\
\hline 13 & - Japan & 22 & 39,048 & 13 & 90.14 & 21 & 3.28 & 16 & 52.7 & 3 & 179,910 & - & - \\
\hline 14 & ;*: South Korea & 26 & 30,644 & 17 & 89.06 & 9 & 3.55 & 10 & 56.11 & 4 & 125,661 & 11 & 175,261 \\
\hline 15 & Taiwan & 28 & 26,910 & - & - & 17 & 3.37 & $10^{*}$ & 83.52 & 5 & 57,886 & - & 43,385 \\
\hline 16 & Lithuania & 38 & 19,883 & 32 & 83.97 & 27 & 3.20 & 40 & 39.18 & - & 112 & - & 6,449 \\
\hline 17 & China & 59 & 10,839 & 100 & 66.12 & 38 & 2.80 & 14 & 53.28 & 1 & 452,804 & 1 & $\begin{array}{r}6,405,62 \\
2\end{array}$ \\
\hline 18 & Russia & 61 & 9,972 & & 72.56 & 46 & 2.69 & 47 & 35.63 & 6 & 34,008 & 9 & 193,828 \\
\hline
\end{tabular}

GDP Per capital Nominal 2020 est. International Monetary Fund, Washington DC. Social Progress Index, 2020, Social Progress Imperative, US. Tech Strength, 2020, Global Finance, NY. World Global Innovation Index 2020, World Intellectual Property Organization (WIPO), Geneva, Switzerland. *Ranked by Bloomberg, 2020. World Patent Grants, 2019, Statista, NY, World Intellectual Property Organization (WIPO), Geneva, Switzerland. World trademarks in force, 2019, World Intellectual Property Organization (WIPO), Geneva, Switzerland 
knowledge economy rating, it has many social problems such as income disparity between cities, high racialism, high crime rates, poor health care and unequal usage of IT, and hence, it does not meet the knowledge economy criteria. Also excluded are Saudi Arabia and Bahrain (poor social progress, poor innovation and poor IP data). So the apparent knowledge economy countries appear to relate to Luxembourg, Australia, the Netherlands, Sweden, Finland, Germany, Canada, Israel, France, UK, Japan, South Korea, Taiwan (China) and Lithuania. But the inability to control the Covid-19 pandemic has dented some of these countries from being an apparent knowledge economy. Of the countries selected, only China managed to have the pandemic under control but its moderate GDP and low social progress have dampened her to be a candidate of apparent knowledge economy. Therefore, it appears that only Luxembourg, Australia, Finland, South Korea, Taiwan (China) and Lithuania satisfy the knowledge economy criteria.

\section{Conclusions and Discussion}

Despite nearly 58 years since the term knowledge economy first appears, we are no nearer in understanding this new kind of economy. This lack of understanding is exacerbated as there is no universal acceptance of the definition of knowledge, knowledge creation, knowledge economy, knowledge society, service economy, network society, etc., and various associated terms such as knowledge, knowledge creation and socialization. Thus, as a result, significant doubts are caused concerns as to whether the 'modern economies' are, indeed, 'knowledge economies'. It does not follow that only those countries transformed to servicing industries and to creating 'knowledge' in so-called knowledge work (white-collared jobs) will thrive to be transformed into knowledge economies. More critically, the current economic meltdown of these so-called knowledge economies is testimonies of false assertion by the precursors of the field. Such inadequacy occurs in view of the fact that the field has no shortage of writers and critics that advance or reject various avenues of the knowledge economy.

In this study, we have made a thorough examination of what the precursors have written about the knowledge economy and what the commenters have argued to put forward what a knowledge economy ought to be. The notion of the knowledge economy must be viewed from some phenomena that have transformed the contemporary economy, but in our content and critical analyses, none of the precursors has advocated an economic system that deals with the fundamentals of the factors of production and how these factors influence society. We, however, found that the works of Nonaka and Takeuchi received some favourable commentaries and we consider that they had initiated a difficult paradigm of articulating tacit knowledge in the conception of knowledge in knowledge creation (management) which if properly transferred (applied) among knowledge workers would lead to the sustaining of competitive advantage of firms and the collective effort of firms would enable the country to prosper in the future. 
This study finds that the study of the knowledge economy is largely speculative where each precursor prescribes what knowledge, information or network ought to be, and suggests a particular economic system (society) that the precursor opines to be appropriate to be used in a particular time period. As such, the field has not been developed into a coherent study of social-economic knowledge, innovation thoughts and technology and knowledge products. Nevertheless, we found the field is interesting and has research usefulness. We achieve three major findings and hence offer these suggestions.

1. We do not need the multiplicity of terms to describe one thing (subject matter); all we need is to use the caption 'knowledge economy' in describing the contents of this new form of economy-i.e. by adopting the path of science, we define the field by its theory, not term. We see the term 'knowledge economy' and 'knowledge society' to be synonymous as an economy that utilizes knowledge to transform work into knowledge products progresses to become a knowledge economy. Likewise, knowledge workers who have successfully developed knowledge products would like to have personal enjoyment.

2. Using the notion of common ground, we articulate that the theoretical foundation of the knowledge economy is (1) a branch of social economy where the starting point is the mid-1990s and (2) not really an economy based solely on production and consumption by exploiting labour and capital, but it is based more on social values, technology and knowledge and innovation to commercialize knowledge products.

3. Using a novel methodology based on proxies, we found that our defined knowledge economy countries are those that satisfy the four criteria: sociability, high-technology adoption, possession of knowledge and innovation to produce knowledge products rather than merely having a high income or apparent high level of social progress, tech strength or innovation. We find tech-strength and innovation indexes wanting, but nevertheless, we include them in our analysis as data to proxy for technology and innovation is hard to come by.

As there is disparity in wealth, employment prospect, social equality, technology availability, innovation, education level and mindset in different countries or regions within a country, our defined knowledge economy can only be found in a few countries.

Acknowledgements We would like to express our thanks of gratitude to the editor, Prof Elias G. Carayannis, Editor-in-Chief, for his comments as well as an anonymous reviewer who have for their insightful suggestions and careful reading of the manuscript.

\section{References}

Abdulla, R. A. (2007). The Internet in the Arab World. Germany: Peter Lang Publishing.

Aghion, P., Blundell, R., Griffith, R., Howitt, P., \& Prantl, S. (2004). Entry and productivity growth: Evidence from microlevel panel data. Journal of the European Economic Association, 2 (2 \& 3), $265-276$. 
Allagui, I. (2009). Multiple mirrors of the Arab digital gap. Global Media Journal (online) 8(4).

Allal-Chérif, O., \& Makhlouf, M. (2016). Using serious games to manage knowledge: The SECI model perspective. Journal of Business Research., 69(5), 1539-1543.

Apte, U. M., Nath, H. K. (2004). Size, structure and growth of the US Information Technology. Southern Methodist Church and Sam Houston State University.

Arrow, K. J. (1984). The economics of information. Cambridge, MA: Harvard University Press.

Bankwatch. (2017) Broken rivers. The impacts of European-financed small hydropower plants on pristine Balkan landscapes. https://bankwatch.org/wp-content/uploads/2017/12/broken-rivers. pdf. Accessed on 12 Dec 2020.

Bell, D. (1973). The coming of post-industrial society: A venture in social forecasting. New York: Basic Books.

Bell, D. (1974). The coming of post-industrial society: A venture in social forecasting. London: Heinemann.

Bell, D. (1979). The social framework of the information society. In M. L. Dertoozos \& J. Moses (Eds.), The computer age: A 20 year view (pp. 500-549). Cambridge, MA: MIT Press.

Bell, D. (1980). The winding passage: Essays and sociological journeys, 1960-1980. Cambridge, Massachusetts: Abt Books.

Berners-Lee, T. (2010). Long live the web: A call for continued open standards and neutrality. Scientific American 11.

Besley, T., Dewatripont, M., \& Guriev, S. (2020). Transition and transition impact: A review of the concept and implications for the EBRD. London: European Bank for Reconstruction and Development.

Bloomberg Innovation Index. (2020). Bloomberg, NY, https://www.bloomberg.com/graphics/2015innovative-countries/. Accessed on 22 Dec 2020.

Brown, L. (2008). Mount Saint Vincent University, social economy and sustainability research network (Partenariat sur l'economie sociale et la durabilite), http://www.msvu.ca/socialeconomyatlantic/ english/whatisE.asp. Accessed on 26 Dec 2015.

Castells, M. (1996). The net and the self: working notes for a critical theory of the informational society. Critique of Antropology. Sage: London.

Castells, M. (1997). The power of identity, the information age: Economy, society and culture (Vol. II). Cambridge, MA: Wiley-Blackwell.

Castells, M. (2000a). Materials for an exploratory theory of the network society. British Journal of Sociology, 51(1), 5-24.

Castells, M. (2000b). The rise of the network society (2nd ed.). U.S.: Blackwell Publishing.

Castells, M. (2010). End of millennium, the information age: Economy, society and culture Vol. III. 2nd. Edition, Wiley-Blackwell, Cambridge, MA.

Chae, B., \& Bloodgood, J. (2006). The paradoxes of knowledge management: An eastern philosophical perspective. Information and Organization, 16(1), 1-26.

Choo, W. C. (1998). The knowing organization: How organizations use information to construct meaning, create knowledge and make decisions. Oxford: Oxford University Press.

Choong, K. K. (2008). Intellectual capital: Definitions, categorization and reporting models. Journal of Intellectual Capital, 9(4), 609-638.

Choong, K. K. (2014). Has this large number of performance measurement publications contributed to its better understanding? A systematic review for research and applications. International Journal of Production Research, 52(14), 4174-4197.

Conklin, D. (1991). Comparative economic systems. Cambridge: Cambridge University Press.

Connell, C. M. (2007). Fritz Machlup's methodology and the theory of the growth of the firm. Quarterly Journal of Austrian Economics, 10(4), 300-312.

Cornish, E. (2011). Daniel Bell and the post-industrial society. Futurist, The.FindArticles.com, http:// findarticles.com/. Accessed on 13 Oct 2014.

Davenport, T. H. (2005). Thinking for a living: How to get better performance and results from knowledge workers. Boston: Harvard University Press.

Davenport, T. H., \& Glaser, J. (2002). Just-in-time delivery comes to knowledge management. Harvard Business Review, 80(7), 107-111.

Davenport, T. H., \& Prusak, L. (1998). Working knowledge: How organizations manage what they know. Harvard Business School Press, Boston.

Davenport, T. H., \& Prusak, L. (2000). Working knowledge: How organizations manage what they know. Harvard Business School Press: Boston. 
Davenport, T. H., \& Volpel, S. E. (2001). The rise of knowledge towards attention management. Journal of Knowledge Management, 5(3), 212-221.

Demoustier, D. (2004). Social economy as social science and practice: Historical perspectives on France (pp. 8-11). Eleventh World Congress of Social Economics Social Economics: A Paradigm for a Global Society, Albertville, France, June.

Desouza, K. C., Awazu, Y., Jha, S., Dombrowski, C., Papagari, S., Baloh, P., \& Kim, J. Y. (2008). Customerdriven innovation - To be a marketplace leader, let your customers drive. Research Technology Management, 51(3), 35-44.

Di Maggio, P., Celeste, C. (2004). Technological careers: Adoption, deepening and dropping out in a panel of Internet users, Working paper, Princeton University.

Drucker, P. (1969). The age of discontinuity. Butterworth-Heinemann: Oxford.

Drucker, P. (1973). Butterworth-Heinemann, Harper \& Row: New York.

Drucker, P. (1999). Management challenges for the 21st century. Harper Business: New York.

Drucker, P. (1992a). The Age of Discontinuity. N Y: Guidelines to our changing society. Harper \& Row.

Drucker, P. (1992b). Managing for the future: The 1990s and beyond. Oxford: Butterworth-Heinemann.

Drucker, P. (1993). Post-capitalist society. Oxford: Butterworth-Heinemann.

Edersheim, E. H. (2007). The definitive Drucker. NY: McGraw-Hill.

Eissa, N. (2020). Pandemic preparedness and public health expenditure. The Economics of Health Outbreaks and Epidemics. July.

Engelbrecht, H. J. (1997). A comparison and critical assessment of Porat and Rubin's information economy and Wallis and North's transaction sector. Information Economics \& Policy, 9, 271-290.

European Bank for Reconstruction and Development. (2019). European Bank for Reconstruction and Development. London.

Fuchs, C. (2009). Some reflections on Manuel Castells's book Communication Power. Creative Common License 7(1), 94-108. http://www.triple-c.at

Garnham, N. (2004a). Information society theory as ideology. In Webster, F., (Ed.), The information society reader, Routledge, NY.

Garza-Rodriguez, J., Almeida-Velasco, N., Gonzalez-Morales, S., et al. (2020). The impact of human capital on economic growth: the case of Mexico. Journal of the Knowledge Economy, 11, 660-675.

Giddens, A. (1990). The consequences of modernity. Cambridge: Polity.

Giddens, A. (2001). Sociology (4th ed.). Maidenhead: Polity Press.

Global Finance. (2020, May 7). The 2020 World's Best Innovators. New York. https://www.gfmag.com/ awards-rankings/best-banks-and-financialrankings/worlds-best-innovators-2020

Godin, B. (2004). The new economy: What the concept owes to the OECD". Research Policy, 33(5), $679-690$.

Godin, B. (2006). The knowledge-based economy: Conceptual framework or buzzwork? Journal of Technology Transfer, 31(1), 17-30.

Godin, B. (2008). The knowledge economy: Fritz Machlup's construction of a synthetic concept. In Viale, R., Etzkowitz, H., (Eds.), The capitalization of knowledge. Edward Elgar Publishing, Cheltenham, Glos, UK and Northampton, MA.

Godin, B. (2010). The culture of numbers: From science to innovation. Talk Given to the GovernmentUniversity-Industry Research Roundtable (GUIRR), US National Academy of Sciences, Washington, 21 May, 2010, GUIRR Leadership Dinner.

Gorz, A. (1982). Farewell to the working class. NY: Pluto Press.

Gourlay, S. (2006). Conceptualizing knowledge creation: A critique of Nonaka's theory. Journal of Management Studies, 43(7), 1415-1436.

Gueslin, A. (1987). L'invention de l'e 'conomie sociale. Paris: Economica.

Hadad, S. (2017). Knowledge economy: Characteristics and dimensions. Management Dynamics in the Knowledge Economy., 5(2), 203-225.

Hildreth, P. J., Kimble, C. (2002). The duality of knowledge. Information Research 8(1). Available at http://InformationR.net/ir/8-1/paper142.html

Hodder, I. (1994). The interpretation of documents and material culture. Thousand Oaks etc.: Sage.

Horkheimer, M. (1982). Critical theory. NY: Seabury Press.

Houghton, J., Sheehan, P. (2000). A primer on the knowledge economy. Unpublished Manuscript, Victoria University, Australia.

Huarng, K., \& Mas-Tur, A. (2016). Turning Kurt Lewin on his head: Nothing is so theoretical as a good practice. Journal of Business Research., 69(11), 4725-4731. 
ICTE Solutions, Australia. (2020). The benefits of technology in education. https:// www.ictesolutions. com.au/the-benefits-of-technology-in-education/. Accessed on 2020-December-26.

Institute for Strategy and Competitiveness. (2020). Harvard Business School, https://www.isc.hbs.edu/ research-areas/pages/social-progress-index.aspx. Accessed on 26 Dec 2020.

Isenberg, D. (2010). Oct 4, The myth of the knowledge economy, Economist, London.

Jones, C. (2019 Dec). 12 Critical types of content analysis. Content Science. Review. https://review.contentscience.com/2-critical-types-of-content-analysis/

Jorna, R. (1998). Managing knowledge. Semiotic Review of Books 9 (2). http://www.chass.utoronto.ca/ epc/srb/srb/managingknow.html. Accessed on 2011-April-12.

Kitchenham, B. A., \& Charters, S. (2007). Guidelines for performing systematic literature reviews in software engineering, Technical Report EBSE-2007-01. School of Computer Science and Mathematics, Keele University.

Krippendorff, K. (2004). Content analysis: An introduction to its methodology. Thousand Oaks, CA: Sage.

Kupers, W. (2005). Phenomenology of embodied implicit and narrative knowing. Journal of Knowledge Management, 9(6), 114-133.

Lages, L. VCW-Value creation wheel: Innovation, technology, business, and society, Journal of Business Research, 69(11), 4849-4855.

Leseure, M, Bauer, J, Birdi, K, Neely, A, \& Denyer, D. (2004). Adoption of promising practices: a systematic review of the evidence. International Journal of Management Review, 5-6(3-4), 169-190.

Lettl, C., Herstatt, C., \& Gemünden, H. G. (2006). Users' contributions to radical innovation: Evidence from four cases in the field of medical equipment technology. R\&D Management, 36(3), 251-272.

Lynch, R., \& Jin, Z. (2016). Knowledge and innovation in emerging market multinationals: The expansion paradox. Journal of Business Research, 69(5), 1593-1597.

Machlup, F. (1962). The production and distribution of knowledge in the United States. Princeton, NJ: Princeton University Press.

Machlup, F., \& Mansfield, U. (1970). The Study of information: Interdisciplinary messages. NY: John Wiley and Sons.

Mackay, H. (2001). Investigating the information society. London: Routledge.

Miles, I. (1990). Mapping and measuring the information economy. Library and Information Research Report 77, British Library Board, London.

Moulaert, F., \& Ailenei, O. (2005). Social economy, third sector and solidarity relations: A conceptual synthesis from history to present. Urban Studies, 42(11), 2037-2053.

Muriel, O., Serrat, O. (2009). Disseminating Knowledge Product, Knowledge Solutions, April, Asian Development Bank, Manila.

Nakata, N. (2002). Indigenous knowledge and the cultural interface: Underlying issues at the intersection of knowledge and information systems. IFLA Journal, 28(5), 281-291.

Neslen, A. (2015 December 11). "Major banks put up nearly $€ 1$ bn for controversial Balkan dams, says report". The Guardian. Accessed on 2020-December-26.

Ninacs, W. with assistance from M. Toye. (2002). A review of the theory and practice of social economy / Économie Sociale in Canada SRDC Working Paper Series 02-02, Ottawa, Canada.

Nasioulasa, I., \& Marisb, N. (2011). Toward the digital social economy: Institutionalizing collective action in the everevolving web. Sociology Study, 1(5), 340-345.

Nonaka, I. (1991). The knowledge creating company. Harvard Business Review, 69(1), 96-104.

Nonaka, I. (1994). A Dynamic theory of organizational knowledge creation. Organizational Science, 5(1), 14-37.

Nonaka, I., \& Takeuchi, H. (1995). The knowledge creating company: How Japanese companies create the dynamics of innovation. NY: Oxford University Press.

Nonaka, I., \& von Krogh, G. (2009). Perspective-tacit knowledge and knowledge conversion: Controversy and advancement in organizational knowledge creation theory. Organization Science, 20(3), 635-652.

Norris, P. (2001). Digital divide. Civic engagement, information poverty, and the Internet worldwide. USA: Cambridge University Press

O'Donovan, N. (2020). From knowledge economy to automation anxiety: A growth regime in crisis? New Political Economy, 25(2), 248-266.

Oberg, C. (2010). Customer roles in innovations. International Journal of Innovation Management, 14(6), 989-1101. 
Organisation for Economic Co-operation and Development (OECD). (1995a). Economic Outlook, Volume 1995 Issue 1. OECD, Paris.

Organisation for Economic Co-operation and Development (OECD). (1995b). Economic Outlook, Volume 1995 Issue 2. OECD, Paris.

Organisation for Economic Co-operation and Development (OCED). (1996a). The knowledge-based economy. OECD/GD (96) 102, OECD. Paris.

Organisation for Economic Co-operation and Development (OCED). (1996b). Measuring what people know: Human capital accounting for the knowledge economy. OECD, Paris: OECD/DSTI/ICCP.

Organization for Economic Cooperation and Development (OECD). (1996c). National innovation systems: Proposals for phase II. DSTI/STP/TIP(96)11, OECD, Paris.

Organization for Economic Cooperation and Development (OECD). (1996d). The knowledge-based economy. OECD, Paris: STI Outlook.

Organization for Economic Cooperation and Development (OECD). (1998). Technology. Best Policy Practice, OECD, Paris: productivity and job creation.

Organization for Economic Cooperation and Development (OECD). (2000). A new economy: The changing role of innovation and information technology in growth. Paris: OECD.

Organization for Economic Cooperation and Development (OECD). (2004). OECD Information Technology Outlook. Paris: OECD.

Organisation for Economic Co-operation and Development (OECD). (2010). Innovation Today Intangible Assets are based on COINVEST. Paris: OECD.

Organization for Economic Cooperation and Development (OECD). (2015) L'Organisation de coopération et de développement économiques, The Social Economy: Building Inclusive Economies, http://www.oecd.org/fr/cfe/leed/thesocialeconomybuildinginclusiveeconomies.htm

Ormerod, P. (1997). Butterfly economics. London: Faber.

Oxley, L., Walker, P., Thorns, D., Wang, H. (2007). Exploring the knowledge economy/society: Another example of measurement without theory. Working Paper, University of Canterbury.

Parkinson, C. N., Rustomji, M. K., \& Sapre, S. A. (1987). Peter Drucker: A critical commentary on his philosophy of management. Bombay: India Book House.

Pawlowski, J., \& Bick, M. (2012). The global knowledge management framework: Towards a theory for knowledge management in globally distributed settings. The Electronic Journal of Knowledge Management, 10(1), 92-108.

Peter G. Peterson Foundation. (2020). How does the U.S. Healthcare System compare to other countries? https://www.pgpf.org/blog/2020/07/how-does-the-us-healthcare-system-compare-to-othercountries. Accessed on 24 Dec 2020.

Phillips, F., Yu, C. Y., Hameed, T., \& El Akhdary, M. (2017). The knowledge society's origins and current trajectory. International Journal of Innovation Studies, 1(2), 175-191.

Polanyi, M. (1958). Personal knowledge: Towards a post-critical philosophy. Chicago, IL: University of Chicago Press.

Polanyi, M. (1966). The tacit dimension. London: Routledge and Kegan Paul.

Porat, M. U. (1977). The information economy: Definition and measurement. Washington DC: United States Department of Commerce.

Porat, M. U., Rubin, M. R. (1977). The information economy. Office of Telecommunications Special Publication 77-12, United States Department of Commerce, Washington DC.

Powell, W., \& Snellman, K. (2004). The knowledge economy. Annual Review of Sociology, 30(2), 199-220.

Rahimi, E., Rostami, N. A., Shad, F. S., \& Vafaei, V. (2017). The importance of knowledge management on innovation. Applied mathematics in engineering, management and technology, 5(1), 68-73.

Rice, R. E., \& Haythornthwaite, C. (2006). Perspectives on Internet use: Access, involvement and interaction. In L. A. Lievrouw \& S. Livingstone (Eds.), Handbook of new media: Social shaping and social consequences of ICTs (Updated (student, pp. 92-113). London: Sage.

Rim, G., Kim, G., Hwange, S., et al. (2019). Some problems in statistically assessing the level of knowledge economy. Journal of Knowledge Economy, 10, 974-996.

Roberts, J. (2010). The global knowledge economy in question. Critical Perspectives on International Business, 5(4), 285-303.

Robins, K., \& Webster, F. (1999). Times of the technoculture: From the information society to the virtual life. London: Routledge.

Robinson, P. N., \& Bauer, S. (2011). Introduction to bio-ontologies. Boca Raton, FL: CRC Press, Taylor \& Francis Group LLC. 
Rooney, D., Hearn, G., \& Niriam, A. (Eds.). (2005). Handbook on the knowledge economy. Cheltenham, Glos, UK: Edward Elgan Publishing.

Rooney, D. Hearn, G., \& Kastelle, T. (2012). Knowledge is people doing things, knowledge economies are people doing things with better outcomes or more people. In Handbook on the knowledge economy, volume two. Rooney, D. Hearn, D. \& Kastelle (eds), T. Edward Elgar Publishing, Cheltenham, UK.

Rosker, R. (2014). Epistemology in Chinese philosophy. Stanford Encyclopedia of Philosophy. https:// plato.stanford.edu/entries/chinese-epistemology/. Accessed on 2 May 2017.

Sapru, R. K. (2008). Administrative thesis and management thought. New Delhi: Practice Hall India.

Sarkar, P. R. (1959). revised in 2012. Ananda Marga-Ananda Printers, Kolkata, India: Idea and Ideology.

Sharma, R., Ng, E., Dharmawirya, M., \& Lee, C. (2008). Beyond the digital divide: A conceptual frame work for analyzing knowledge societies. Journal of Knowledge Management, 12(5), 151-164.

Shield, S. (2020). The EBRD, fail forward neoliberalism and the construction of the European periphery. The Economic and Labour Relations Review. April. https://journals.sagepub.com/doi/full/10.1177/ 1035304620916652. Accessed on 26 Dec 2020.

Smith, M. K. (2002). What is the 'knowledge economy'? Knowledge Intensity and Distributed Knowledge Bases: United Nations University, Institute for New Technologies.

Styhre, A. (2003). Understanding knowledge management: Critical and postmodern perspectives. Copenhagen: Copenhagen Business School Press.

Swan, J., \& Scarborough, H. (2002). The paradox of 'knowledge management.' Informatik Informatique, $1,10-13$.

The Straits Times. (2020 October 16). Bid to fix fault led to disruption of 3 MRT lines. https://www.straitstimes.com/singapore/bid-to-fix-fault-led-to-disruption-of-3-mrt-lines. Accessed on 26 Dec 2020.

UNESCO. (2003). Towards knowledge societies. (by Abdul Waheed Khan (General sub-director of UNESCO for $\neg$ Communication and Information)). In A World of Science 1(4), United Nations Educational, Scientific and Cultural Organizations, Paris. http://www.unesco.org/science/world_ sc_july03.pdf. Accessed on 17 Oct 2017.

UNESCO. (2005). Towards knowledge societies. United Nations Educational: Scientific and Cultural Organizations (UNESCO) Publishing, Paris.

Van Dijk, J. (1999). The network society: Social aspects of new media. Thousand Oaks, London (original Dutch edition, 1991, De netwerkmaastchappij Bohn Staflen Van Loghum, Houten).

Van Dijk, J. (2006). The network society: Social aspects of new media. London: Thousand Oaks.

Von Krogh, G., Ichijō, K., \& Nonaka, I. (2000). Enabling knowledge creation: How to unlock the mystery of tacit knowledge and release the power of innovation. NY: Oxford University Press.

Von Krogh, G., Nonaka, I., \& Nishiguchi, T. (2000). Knowledge creation: A source of value. NY: Palgrave Macmillan.

Wang, J. (2018). Innovation and government intervention: A comparison of Singapore and Hong Kong. Research Policy, 47(2),399-412.

Waters, M. (1996). Daniel Bell - A critical but favorable intellectual biography. London: Routledge.

Webster, F. (2002a). Theories of the information society (2nd ed.). London: Routledge.

Webster, F. (2002b). The information society revisited. In L. Lievrouw \& S. Livingstone (Eds.), Handbook of New Media (pp. 255-266). London: Sage.

Webster, F. (2004). Information and urban change: Manuel Castells. In F. Webster \& B. Dimitriou (Eds.), Manuel Castells - (Vol. II, pp. 15-39). London: Sage Publications.

Wellenius, B. (1988). Foreword: Concepts and issues on information sector measurement. In: Jussawalla, M., Lamberton, D., Karunaratne, N., (Eds.), The cost of Thinking: Information Economics of Ten Pacific Countries. Ablex, Norwood, NJ.

Wilson, T. D. (2002). The nonsense of 'knowledge management'. Information Research 8(1), available at http://InformationR.net/8-1. Retrieved 12 May 2011.

World Bank. (2020). Current health expenditure (percentage of GDP). https://data.worldbank.org/ indicator/SH.XPD.CHEX.GD.ZS. Washington DC. Accessed on 22 Dec 2020.

World Intellectual Property Organization Statistics. (2020). World Intellectual Property Organization (WIPO), Geneva, Switzerland, http://www.wipo.int/ipstats/en/. Accessed on 22 Dec 2020.

ZDNet. (2020). Singapore government ups ICT spending by $30 \%$ to fuel post-pandemic recovery, digital transformation. https://www.zdnet.com/article/singapore-government-ups-ict-spending-by-30-tofuel-post-pandemic-recovery-digital-transformation/. Accessed on 26 Dec 2020. 
Zhu, A. Y. F., \& Chou, K. L. (2020). Hong Kong's transition toward a knowledge economy: Analyzing effect of overeducation on wages between 1991 and 2011. Journal of the Knowledge Economy, 11, $103-113$.

Publisher's Note Springer Nature remains neutral with regard to jurisdictional claims in published maps and institutional affiliations.

\section{Authors and Affiliations}

\section{Kwee Keong Choong ${ }^{1}$. Patrick W. Leung ${ }^{2}$}

1 Apt Visionary \& Innovation, Melbourne, Australia

2 Department of Accounting, The Hong Kong University of Science and Technology, Clear Water Bay, Hong Kong SAR, China 